\title{
La Junta del Almirantazgo y la lucha contra el contrabando, 1625-1643
}

\author{
Angel Alloza Aparicio \\ UNED, Madrid
}

\section{RESUMEN:}

Este artículo examina el papel que el contrabando desempeñó respec-

to a los mecanismos de guerra económica diseñados por la Monarquía Católica para combatir a sus adversarios en el ámbito europeo durante la primera mitad del siglo $X V I I$. En él se analizan los ingresos

y gastos registrados por la Junta del Almirantazgo, como órgano encargado de perseguir el comercio ilegal, desde el inicio de su andadura en 1626 hasta su reforma e inclusión en el Consejo de Guerra en 1643. El estudio revela también datos muy interesantes sobre el importe del dinero procedido de las licencias especiales, o permisiones para introducir productos de contrabando de guerra.

\begin{abstract}
This article examines the role played by the illegal trade, or smuggling, with respect to the instruments of economic war designed by the Catholic Monarchy to fight her enemies in Europe during the first half of the Seventeenth Century. The income and expenses of the Junta del Aimirantazgo, as the institution in charge to prosecute illicit trade between 1625 and 1643, are analyzed in the paper. The study also reveals some interesting data on special permissions to import contraband goods.
\end{abstract}

1. INTRODUCCIÓN: MERCANTILISMO, GUERRA ECONÓMICA Y CONTRABANDO EN LA PRIMERA MITAD DEL SIGLO XVII.

"Podemos decir que las indias han sido causa de hallarse estos reinos con poca población, y sin piata, cargados de obligaciones de política costosa en trajes, y gastos, sirviendo de puente de la conducción de plata para otros

\footnotetext{
'. Este trabajo se inscribe dentro del proyecto «ESCOMARIN", BHA2000-0183-C02-01, del Programa Nacional de Promoción General del Conocimiento.
} 
reinos, que todo hubiera podido quedar en estos de Vuestra Majestad si lo que pasó a las Indias hubiera sido cosecha y fábrica de estos reinos; mas habiéndose valido de los extranjeros los ha engranado en el mismo especie de plata". 2

Este fragmento del memorial presentado a Felipe IV a comienzos de 1628 por mercaderes del Almirantazgo, respondiendo a los inconvenientes que resultaban de la aplicación de la Tasa de 1627, reproduce algunos de los análisis que se manejaron sobre la decadencia de España y de su comercio exterior a comienzos de la centuria del Seiscientos. Aunque el motivo principal de la carta era protestar contra el establecimiento de una tasa general de artículos de primera necesidad — cuyo objeto era impedir que éstos subieran aún más de lo que se estaban incrementando debido a la coyuntura inflacionista- los firmantes no perdieron la ocasión de representar también los efectos desastrosos que las restricciones al tráfico comercial causaban a la mermada comunidad mercantil de la Monarquía, como las prohibiciones de introducir determinadas mercancías, la decisión de que los retornos de las importaciones se hiciesen en productos nacionales y no en dinero, la inestabilidad de la moneda, así como la aplicación de la Pragmática de Reformación de 1623, cuyos capítulos 12 y 13 intentaban poner freno a la importación de manufacturas a fin de mejorar la balanza de pagos, fomentar la industria castellana e impedir la salida de plata del reino. Restricciones que, según sus autores, perjudicaban enormemente a la Hacienda Real, a causa de la disminución de ingresos de almojarifazgos, aduanas y puertos secos, que a la postre hacía quebrar algunas rentas y los juros que había sobre ellas.

El memorial venía a concluir que el monopolio de las Indias era una quimera, porque las naciones extranjeras no estaban dispuestas a dejar de participar en las riquezas del Nuevo Mundo, y que lo harían ya fuera de forma legal, ilegal o por la fuerza. Punto por punto, el informe reproducía los aspectos principales de una controversia que sobre el mercantilismo frente a la libertad de comercio se venía desarrollando desde mediados del reinado de Felipe II -más concretamente desde el inicio de la rebelión de los Países Bajos - y que incluía reflexiones sobre las posibilidades y efectos de la guerra económica. Como ya sucediera en los reinados de Carlos V y Felipe II, la práctica de gobierno de sus sucesores reveló claramente el triunfo de las posiciones más beligerantes, es decir, aquellas orientadas al mantenimiento a toda costa del monopolio de las Indias y el cierre de los mercados americano y español a los adversarios. Si bien, al-

2. Representación de la Junta del Almirantazgo sobre los daños que trajo el descubrimiento de las Indias... se presentó a Su Majestad en 1628. GonzÁlez dE SALCEDO, P., Tratado jurídico-político del contrabando, capítulo III. 1654. (se ha manejado la tercera edición de esta obra, impresa en Madrid, en 1729). 
gunas voces informadas como la del contador Antonio de Rojas, el veedor de comercio Francisco de Retama, o la de expertos como Alberto Struzzi, advirtieron de la inutilidad de la guerra comercial, que según sus criterios sólo lograba forzar al enemigo a pasar a la ofensiva - como ya lo venía haciendo Holanda en las Indias Orientales- así como a abrir el camino del contrabando. Estos autores postularon la libertad de comercio, o en el menor de los casos una orientación y apertura razonables del mismo, apoyada en aranceles sobre ciertas materias primas como la lana. ${ }^{3}$

El monopolio español del metal precioso y del suministro de índigo, cochinilla, tabaco y palo campeche; el de la sal de calidad - vital para las industrias pesqueras de Holanda, Escandinavia y el tráfico holandés en el Norte-, así como del azúcar de Brasil y la posesión en exclusiva de la lana merina de Castilla, elevaban las ambiciones de la Monarquía Católica de dominar el comercio mundial. Pero la dependencia de trigo de la región del Báltico, de especias como pimienta y canela procedentes de las Indias Orientales, así como de pertrechos navales, arboladura y cobre de los países septentrionales, dio al traste con sus aspiraciones. Esta necesidad de productos fabricados o transportados por el enemigo imposibilitaba el cierre inescrutable de los mercados de la Monarquía, ya que el contrabando y las licencias especiales para introducir mercancías vetadas les hacian permeables. Para algunos historiadores esta permeabilidad de los mercados ha constituido suficiente razón como para concluir que el impacto de las medidas de guerra económica adoptadas por los sucesivos gobiernos de los Austrias fue mínimo e ineficaz. ${ }^{4}$

Sin embargo, aunque el conocimiento actual sobre el contrabando y las licencias especiales en el siglo XVII es todavia escaso, es ya suficiente como para afirmar la relevancia de la guerra económica como una herramienta poderosa capaz de herir el comercio enemigo y dañar su producción de manufacturas. ${ }^{5}$ Hay que admitir que el asunto de las licencias especiales se revela contradictorio, pues si bien es cierto demostraban la

\footnotetext{
${ }^{3}$ Ver Larraz, J., La época del mercantilismo en Castilla. Salamanca, 2000; Echeverría Vacigalupe, M. A., "Examen de una polémica sobre los intercambios exteriores a principios del siglo XVII", Estudia Histórica, 3 (1985) págs. 119-142, y del mismo autor «Una original contribución al pensamiento antimercantilista: la doctrina Struzzi de 1629", Hispania, 167 (1987) págs. 897-928; ver también Domínguez Ortiz, A., "Guerra económica y comercio extranjero en el reinado de Felipe IV ", Hispania, 89 (1963), pp. 71-110. El memorial de Francisco de Retama en Archivo General de Simancas (en adelante A.G.S.) Estado, Legajo 2.847.

4 Ver, por ejemplo, Alcalá-Zamora, J., España, Flandes y el mar del Norte (1618-1639). BarceIona, 1975 y Gómez-Centurión, C., Felipe II, la empresa de Inglaterra y el comercio septentrional (1566-1609). Madrid, 1988.

${ }^{5}$ Las represalias efectuadas contra holandeses (1598-1648) ingleses $(1595,1625$ y 1656$)$ franceses $(1625,1635,1667,1674)$ portugueses (1641) constituyen buena muestra de los daños infligidos al enemigo en el terreno comercial. Me he ocupado de este asunto en "Guerra económica y comercio europeo en España. la política de represalias y embargos en el siglo XVII» (en prensa).
} 
inutilidad de prohibir el comercio con estados de cuyos productos se carecía, también lo es que el desabastecimiento de los mismos se producía como resultado de las prohibiciones y medidas protectoras del tráfico comercial, de lo que se infiere la eficacia de los bloqueos. ${ }^{6}$

Por lo que se refiere al contrabando, las siguientes páginas mostrarán que este fenómeno se persiguió con denuedo desde múltiples plataformas, y que los resultados de esta lucha, aunque insuficientes, fueron palpables a corto y medio plazo, y no sólo en el ámbito de las importaciones, sino también en el relativo al transporte, los seguros, y la propia producción de manufacturas. En todo caso se pueden anticipar hechos como que el contrabando de productos de Holanda desde 1621, efectuado vía Navarra, Portugal o Alicante, en modo alguno llegó a equivaler el valor de las mercancías transportadas por los más de 800 barcos neerlandeses que según el memorialista Francisco de Retama visitaban cada año los puertos españoles durante la tregua. ${ }^{7}$ O que tras la prohibición del comercio con Francia en 1635 se produjera un desabastecimiento importante de productos como trigo y pescado en muchas localidades de Castilla y del Norte.

Con el objeto de justipreciar el papel que el contrabando jugó con respecto a los intereses de la Monarquía Católica en el ámbito europeo durante la primera mitad del siglo XVII, este trabajo examina los ingresos registrados por la Junta del Almirantazgo, como órgano encargado de perseguir el comercio ilegal, desde el inicio de su andadura en 1626 hasta su reforma e inclusión en el Consejo de Guerra en 1643. Para ello se han vaciado y analizado unas fuentes de inestimable valor, depositadas en el Archivo General de Simancas, cuyo contenido principal lo constituye el cargo y la data de don Francisco de Manzano, receptor de dicha Junta. Otras fuentes consultadas en ese mismo archivo, en las secciones de Estado, Consejo y Juntas de Hacienda, y Guerra y Marina, junto con diverso material recopilado en el Archivo Histórico Nacional, revelan también datos inéditos y muy interesantes sobre el importe total del dinero procedido de las licencias especiales, o permisiones para importar productos de contrabando de guerra. La evidencia histórica presentada en este artículo forma parte de una investigación de mayor alcance sobre la guerra económica y el comercio exterior de España en la centuria del Seiscientos.

\footnotetext{
' Son algunas ideas recogidas en HerRero SánChez, M., «La política de embargos y el contrabando de productos de lujo en Madrid (1635-1673). Sociedad cortesana y dependencia de los mercados internacionales", Hispania, 201 (1999) págs. 171-191.

7 A.G.S., Estado, Legajo 2.847. Un informe recibido por la Junta del Almirantazgo en 1630 revelaba que en Castilla entraban cada año mercancías holandesas de contrabando por valor de dos o tres millones de ducados, aunque un escrito anterior elevaba la cifra a diez millones. BroENS, N., Monarquía y Capital Mercantil: Felipe IV y las Redes Comerciales Portuguesas (1627-1635). Madrid, 1989. pág. 29.
} 


\section{LA JUNTA DEL ALMIRANTAZGO (1625-1643).}

Poner freno a la disminución registrada en el comercio flamenco y alemán con España tras el fin de la tregua con las Provincias Unidas en 1621, e impedir el contrabando rebelde y enemigo, constituyeron los objetivos de partida del naciente Almirantazgo de los Países Septentrionales en octubre de 1624, cuya sede se estableció en Sevilla. Su diseño incluía la formación de una escuadra compuesta por 24 navíos de guerra para garantizar la seguridad del tráfico con los estados del Norte, seriamente amenazado tras la reanudación de la lucha con Holanda; así como la creación de un consejo, junta y tribunal en Madrid, con agentes repartidos en toda la $\mathrm{Pe}$ nínsula - los veedores del contrabando- para vigilar y reprimir el comercio con los enemigos de la Monarquía. Este nuevo organismo, conocido como Junta del Almirantazgo, se estableció en la capital el día 13 de enero de 1625. Mientras el órgano de Sevilla tenía encomendado el depósito de las fianzas que los mercaderes del comercio de septentrión habían de abonar como garantía de que sus exportaciones no llegaban a manos rebeldes ni a las de sus aliados, la Junta de Madrid se ocupaba de evitar, por medio de las visitas e inspecciones realizadas por los veedores, que los barcos de otras naciones no introdujeran en España mercancias de enemigos, confiscando aquellas que el tribunal declarase de contrabando. ${ }^{8}$

La inviabilidad del transporte en convoys hacia el Norte, así como las fuertes resistencias a las fianzas impuestas a los cargadores para sacar "productos de la tierra", pronto dieron al traste con el Almirantazgo de Sevilla, cuyas últimas actuaciones se registran a fines de 1628, mas no ocurrió lo mismo con la Junta de Madrid, que gracias al sistema de veedores que había establecido en los puertos más importantes de la Península, así como al celo con que éstos trataban de aprehender mercancías de contrabando, logró permanecer en activo hasta abril de 1643, fecha en la cual Felipe IV unificó la Junta del Almirantazgo y la de represalia de franceses creada en 1635- poniéndolas bajo control de los contadores del sueldo Diego Olmos y Diego de Gozenaga, e integrándola en el Consejo de Guerra. ${ }^{9}$ Pero no es casualidad que la Junta del Almirantazgo lograse sobrevi-

\footnotetext{
- Sobre los fundamentos institucionaies de este organismo pueden verse los estudios de DoMínguez Ortiz, A., "El Almirantazgo de los países septentrionales y la política económica de Felipe IV", Hispania, XXVI (1947), págs. 272-290; De la CONCHA, I., “El Almirantazgo de Sevilla. Notas para el estudio de las instituciones mercantiles en la Edad Moderna", Anuario de Historia del Derecho Español, XIX (1948), págs. 459-525; y DIAZ GonZÁLZZ, F.J., La Junta del Almirantazgo: Órgano de Gobierno y Tribunal de Apelación. Tesis Doctoral, Universidad de Alcalá de Henares, 1999.

${ }^{9}$ A.G.S. Contaduría del Sueido, $2^{\mathrm{a}}$ serie, Leg. 150 (1). Algunos autores alargan la vida de la Junta hasta 1661, y otros incluso hasta fines del siglo XVil. Véase el artículo citado de Herrero Sánchez, y también Pulido Bueno, I., Almojarifazgos y comercio exterior en Andalucía durante la época mercantilista. 1526-1740. Huelva, 1993. Págs. 26-36.
} 
vir durante casi dos décadas en aquellos turbulentos años: la cláusula número $18 \mathrm{del}$ acta fundacional hacía beneficiaria a la institución de las confiscaciones de navíos, bienes y mercaderías prohibidas pertenecientes a rebeldes o enemigos que, por presa o denunciación, tomasen en los puertos o en alta mar, y se condenasen por contrabando.

Por añadidura, existían grandes incentivos para denunciar el comercio ilegal, ya que el sistema de reparto de las confiscaciones se efectuaba por lo común en tres partes, una para el denunciador, otra para el juez o veedor, y la tercera para la Real Hacienda, representada por la Junta del Almirantazgo (las presas del Corso solían repartirse en cinco partes) De modo que el incentivo a los denunciadores y la avidez de dinero por parte de los jueces y veedores de contrabando, o en su caso corregidores, constituyeron un gran estímulo para la lucha contra el comercio ilegal. Tanto es así que cuando el gobernador de Flandes intentó extender en España la cédula que había publicado a comienzos de 1628 permitiendo a los denunciadores apropiarse de todo lo que se denunciase en los barcos, salvo el vaso, que era para Su Majestad, el Almirantazgo protestó argumentando que semejante ley iba en contra de sus privilegios. Tras escuchar la opinión de Montesclaros, presidente de la Junta de comercio y miembro del Consejo de Hacienda, el Rey resolvió que era mejor dar solamente la mitad del botín a los marineros denunciadores, y la otra mitad a repartir entre la cámara y el juez. ${ }^{10}$

La oposición de influyentes mercaderes, elevada en forma de quejas a los consejos de Hacienda e Indias, a la Junta de Comercio, y aun al propio Monarca, debida a los procedimientos del Almirantazgo en el registro e inspección de los buques, asi como a las fianzas que habían de depositar para dirigir las exportaciones a naciones amigas, trayendo testimonios válidos de las consignaciones a sus dueños, constituyeron serios motivos de disgusto que a la postre lastrarian la actividad de la institución sevillana hasta hacerla incluso desaparecer. Si bien, una notable diferencia entre el Almirantazgo de Sevilla y la Junta de Madrid es que las quejas surgidas contra el organismo sevillano provenían del comercio amigo, mientras que las elevadas contra la Junta venían dirigidas sobre todo del enemigo. En ningún caso se trataba de protestas sin fundamento. En una ocasión, a comienzos de 1628, el corregidor de Málaga redactó un informe criticando la actuación de un navío del Almirantazgo que habia apresado un buque inglés pero dejando escapar tres holandeses, a pesar de la ayuda que la ciudad le había ofrecido. ${ }^{11}$

Más serios todavía se revelaron los inconvenientes puestos de manifiesto por la Audiencia de Sevilla en una carta dirigida al Rey en septiembre

${ }^{10}$ A.G.S., Estado, Legajo 2.645. Y ello a pesar de que Montesclaros veía bien la idea, pues en definitiva -decía- se irataba de impedir el comercio rebelde poniendo todos los medios necesarios, sirn atender a los intereses del Almirantazgo.

${ }^{11}$ Archivo Histórico Nacional (en adelante A.H.N.) Consejos, Legajo 51.443 (4). 
de 1627, en la cual apuntaba que desde que se dictó la cédula ordenando las fianzas a la exportación y exigiendo certificados de los consignatarios, se habían dejado de exportar dos millones de ducados de frutos de la tierra. El escrito explicitaba que solían venir todos los años alrededor de 200 barcos pequeños con mercaderías pertenecientes a maestres y marineros, los cuales a su regreso se llevaban frutos nacionales, "y que por no poder hacer frente a las licencias habian dejado de venir". La misiva terminaba afirmando que la guerra de Inglaterra había provocado el embargo y confiscación "de gran suma de ducados", lo que añadido al asunto de las fianzas, había provocado el abandono de España de muchos mercaderes, con reconocido daño a los almojarifazgos. Ante estos argumentos el Almirantazgo se defendió mediante una representación en la que demostraba que las fianzas no habían estorbado la saca de muchas mercadurías, ya que desde el día 19 de julio de 1626 hasta fines de octubre de 1627 se habían cargado 73.141.652 maravedíes, y que el mismo Guillermo Reinar, juez y contador mayor del Almirantazgo que daba esta certificación, era uno de los principales cargadores incluidos en ella, "Y en tan poca suma le toca a él por su certificación haber cargado más de trece cuentos en que se puede creer no se habrá reparado mucho en las fianzas". ${ }^{12}$

Fueron, al parecer, los informes negativos del Consejo de Indias sobre la exigencia de las fianzas los factores que más peso tuvieron para que $\mathrm{Fe}$ lipe IV adoptase finalmente la decisión de suspenderlas. Por un lado, el Consejo opinaba que las fianzas exigidas a los cargadores no aseguraban lo que se pretendia, que era impedir al enemigo el abastecimiento de productos que necesitaba, ya que las cautelas que se tomaban para evitarlo eran muy fáciles de contravenir "y muy sabidas y muy usadas antes y después de este gravamen". Por el otro, observaba que la dificultad para exportar los productos de la tierra llevaba a los cargadores «a malbaratarlos al precio que se los quisieren comprar", lo cual embarazaba mucho la cargazón para las Indias, "que constaba de dos partes tan principales como vender los géneros que de allá venían y comprar los que habían menester para la contratación de todas las provincias». Con lo cual tenía por cierto el Consejo de Indias que el despacho de las flotas cesaría y el asiento de la avería no podría conservarse, pues éste último dependía del volumen de contratación de dichas flotas. ${ }^{13}$

La Junta de Madrid tampoco permaneció exenta de problemas, pero ninguno de ellos tan importante como para llevar a la suspensión de su actividad. Informes recibidos por el Consejo de Estado durante el año 1628 revelaban que los ministros portugueses impedían la aplicación de las nuevas medidas sobre comercio dadas por Felipe IV. Además, algunos envia-

${ }^{12}$ A.G.S., Estado, legajo 2.646

${ }^{13}$ ibídem. 
dos españoles como Fernández de Toledo o veedores de comercio como Hernando de Espina denunciaban el escandaloso comercio inglés y holandés que existia contra toda norma en Lisboa, Oporto y Viana. El Reino de Navarra también ocasionó a la Junta innumerables inconvenientes, no sólo debido a la permanente introducción por su territorio de productos holandeses en Castilla, como constataba el Consejo por múltiples informes que le llegaban, sino también debido a la negativa del Virrey a enviar a la Junta las apelaciones de las denunciaciones de bienes de rebeldes que se hicieron en aquel Reino, apelando a sus fueros aún vigentes. $Y$ todo ello a pesar de la voluntad visible del gobierno de Madrid para luchar desde todos los ángulos contra el contrabando, como se desprendía de la propuesta del fiscal del Consejo de Estado, don Juan de Palafox, de poner en orden todas las leyes del contrabando distribuidas en los consejos de $\mathrm{Ha}$ cienda, Indias y Guerra "de la manera que se ha hecho en las leyes de Recopilación" para luchar con mayor eficacia contra el comercio ilegal. ${ }^{14}$

Quejas sobre las prácticas de los veedores de comercio y contrabando también existieron. En 1632, molestos por las inspecciones de navios, algunos bilbaínos que vivían del comercio expulsaron a los veedores del Almirantazgo, pero dos años más tarde se ordenó de nuevo la confiscación de todas las mercancías que llegasen sin las licencias en regla. ${ }^{15}$ En otra, acusando de corrupción a los jueces del Almirantazgo, un memorial escrito contra ellos afirmaba que las mercancías valdrían un tercio menos si no hubiera que "huntarles» tanto. Pero la Junta del Almirantazgo negaba las acusaciones y se defendía demostrando que gracias a los procedimientos incoados contra los hombres de negocios dedicados a la importación y exportación, muchos de ellos conversos portugueses, se había conseguido de éstos últimos un servicio a Su Majestad de 21.000 ducados y un socorro (crédito) de 100.000. ${ }^{16}$

Este tipo de protestas no era nuevo, sino que se venía registrando con anterioridad a la fundación del Almirantazgo, en especial tras la publicación de la Pragmática de Reformación de 1623, cuyos capítulos 12 y 13 establecían serias restricciones al comercio exterior. Cabe destacar entre ellas las acusaciones efectuadas por los embajadores de Francia e Inglaterra contra Felipe IV de incumplir los tratados firmados en 1598 y 1604 respectivamente. Don Gualtero Aston, embajador inglés, apeló al capítulo 10 de la paz asentada en 1604 que permitía el libre comercio entre los súbditos de ambas coronas, y suplicaba la expedición de una cédula que eximiera a los $c 0-$ merciartes ingieses de los capítulos de la Pragmática. También preocupaban al diplomático británico los registros que los traficantes anglosajones estaban sufriendo

14 A.G.S., Estado, legajo 2.646

${ }^{15}$ Dominguez Ortiz, A., "Guerra Económica.» Op. Cit. pág. 93.

"Este episodio en López Belinchón, 3. J., "Sacar la sustancia del reino". Comercio, contrabando y conversos portugueses, 1621-1640", Hispania, 209 (2001) págs. 1.017-1.050. 
en sus propias casas al objeto de comprobar si las mercancías depositadas en ellas tenían origen holandés o enemigo, las cuales, por cierto, eran muy cuantiosas debido a la ausencia de cargazón para las Indias registrada ese mismo año de 1623. Por su parte, el embajador del rey Cristianísimo pedía el levantamiento de los embargos que habian sufrido en algunos puertos españoles los bienes transportados por franceses, y añadía asimismo que muchos mercaderes que se encontraban navegando con destino a España salieron de puerto antes de publicarse la nueva ley. ${ }^{17}$

Ante el compendio de protestas y súplicas que llegó incluso a las más altas magistraturas del estado, el marqués de Montesclaros mostró un parecer genuinamente proteccionista, y sin impedir el tráfico, postuló se gravase fuertemente lo que venía de fuera y se fomentase el consumo del producto interior. El artículo 12 de la Pragmática de Reformación mandaba que no se pudieran vender ni comprar "en estos reinos ningún género de paño ni tela de seda o lana que no estuviese hecho con la cuenta, marca y ley que disponían las leyes, y que lo que de otra manera se aprehendiese fuera perdido". Esto se oponía claramente a la libertad de comercio en Inglaterra, donde no había obligación de fabricar con la marca, ley o forma con que aquí estaba mandado; por eso Montesclaros, defendiendo a Felipe IV de quien le acusaba de incumplir los tratados de paz y comercio, aconsejaba al rey permitir la entrada de todos estos géneros ingleses pero poniendo precio a aquellos que les faltase algo para llegar a la cuenta, marca y ley exigidas en España a los fabricantes. Con esta justificación no se contravenía lo que estaba asentado en los acuerdos, ni se incumplía lo que les estaba prometido. El capítulo número 13 prohibía la entrada de manufacturas de seda, lana o ambas - excepto tapicerias de Flandes-y de algodón, lienzo, cuero, alquimia, latón, plomo, piedra, concha, cuerno, marfil y pelo, de modo que la contratación de Inglaterra quedaba coartada por todos estos géneros, no pudiendo traer ya ninguno de ellos, ni siquiera aquellos que solían introducir en sumas considerables, como eran medias y alfileres. Pese a todas estas cuestiones que suscitaban los principales grupos de mercaderes extranjeros asentados en los puertos españoles, la Junta del Almirantazgo desarrolló su actividad con más o menos acierto, pero con incuestionable celo, durante casi veinte años. Veamos el alcance de su actuación.

\section{LAS CUENTAS DE LA JUNTA DEL ALMIRANTAZGO EN LA LUCHA CONTRA EL CONTRABANDO.}

Los contrabandos provenientes de las provincias rebeldes -o de su transporte- entre 1621 y 1648 , de Inglaterra entre 1625 y 1630 , el de manufacturas textiles y otros productos de Francia a partir de 1635, y el de

\footnotetext{
${ }^{17}$ A.H.N., Consejos, Legajo 51.443 (4).
} 
Portugal a partir de 1641 , constituyeron el objeto de persecución por parte de los veedores de la Junta desde el comienzo de su andadura en 1625. Sin bien, debido a la falsificación de las licencias de origen de las mercancías, la dificultad existente para distinguir las manufacturadas en Flandes de las producidas por estados enemigos, así como debido a su introducción fraudulenta en buques con bandera de conveniencia, las inspecciones de los veedores del Almirantazgo se extendieron prácticamente a todos los barcos que arribaban en los puertos de la Península, vinieran de donde vinieran, porque de la misma forma que franceses e ingleses habían introducido manufacturas de Holanda antes y después de la tregua, los barcos de la Hansa no dudaron de transportar productos ingleses y franceses cuando su comercio con España estaba prohibido.

\subsection{El cargo.}

Los ingresos registrados por don Francisco de Manzano, receptor de la Junta del Almirantazgo en Madrid, se componían de la tercera parte correspondiente a la Real Hacienda de las confiscaciones que por contrabando se realizaron en los puertos de mar, aduanas y puertos secos de la Península, entre 1625 y 1643. Si bien, las partidas asentadas por este eficaz funcionario, cuya carrera como contador, receptor y tesorero en distintos organismos de la administración de la Monarquia se extendió durante más de 50 años, reflejan muchos otros conceptos que no se ceñían del todo a las confiscaciones, aunque todos ellos tenían que ver con el comercio ilegal, como fueron los relativos a composiciones e indultos por introducir ropa de contrabando, o los ingresos procedentes de la venta de los productos confiscados. Además, como se comprueba en la documentación examinada, no siempre la Junta recibió la tercera parte del importe de los decomisos, sino la mitad, dos tercios o tres cuartas partes de su valor, o a veces simplemente la cantidad que el veedor de comercio y contrabando tuvo a bien enviar a Madrid. Por estas razones, los cargos asentados por Manzano en los balances, aunque registrados con mucha claridad, constituyen un material muy complejo si se pretenden interpretar con exactitud los criterios de la Junta en materia de distribución de las confiscaciones por contrabando.

Mucho más difícil todavía resulta calcular - a partir de estos ingresosla proporción del contrabando en el volumen total del comercio exterior. Esto es debido a las diferencias tan abismales que hemos podido detectar entre los precios corrientes «o de mercado» de los productos de importación y exportación, y los precios a como se vendían los bienes confiscados por contrabando; diferencias que desvirtúan cualquier estimación cuantitativa que se pretenda sobre el peso del tráfico ilegal en el comercio exterior, 
en especial del europeo en España. ${ }^{18}$ En 1629 dos mercaderes flamencos residentes en Madrid, llamados Guillermo de Lovaina y Abraham Lerses, compraron 803 libras de especia de clavo confiscadas por el Almirantazgo al precio de 33 reales la libra, cuando su valor podía alcanzar en el mercado los 46 reales. En 1636 la Junta decomisó en Valmaseda una partida de especia de clavo que vendió a razón de 30 reales la libra, pero su precio en ese momento -según estimaciones de Hamilton-podría llegar a los 60,8 reales. Dos años más tarde, el corregidor de Ágreda vendió 42,5 libras de ese mismo producto a un precio todavía más ridículo: 10,5 reales la libra. Con la pimienta confiscada ocurría lo mismo: las 159 arrobas y media incautadas del navío holandés que dio en Fuengirola en 1637, fueron vendidas a dos reales la libra, cuando su valor en Andalucía podía alcanzar los 12,7 reales. Una pieza de fustanes podía valer hacia 1632 el precio de 80 reales, mientras que la Junta vendía cada pieza confiscada a 25 . En esa misma fecha una hoja de espada bien podía costarle a un artífice 10 reales, pero si éste la compraba al Almirantazgo le podía salir por seis o menos. Son múltiples los ejemplos que proporcionan las fuentes manejadas, las cuales además dejan entrever que muchos mercaderes a quienes los veedores habían confiscado sus cargas las volvían a comprar por personas interpuestas a precios tan bajos que más bien parecian un arancel más. ${ }^{19}$

Por si fuera poco, no a todo el mundo se le vendían los bienes confiscados de contrabando al mismo precio, sino que éste variaba dependiendo de quien fuese el comprador, así como de alguna otra circunstancia que los documentos no reflejan explícitamente pero sí insinúan. El arrendador del estanco de la goma, Jerónimo de Fonseca, compró los nueve barriles de ese producto que habían aprehendido a Carlos Leba en 1634 , a tres reales la libra, cuando su precio corriente podía llegar a seis o siete, según fuese la goma gorda o fina. Sin embargo, el mercader inglés Guillermo Pauley, compró aquel mismo año, a poco más de un real cada una, las 3.853 libras de goma confiscadas a su compatriota Petruen Cuaton. Dos años más tarde compró el mismo Fonseca cerca de 600 libras de goma de contrabando al precio de un real la unidad; y como propina la Junta le regaló otras 25 arrobas más de aquel producto.

${ }^{18}$ No conocemos el criterio seguido en las tasaciones de los productos confiscados pero, teniendo en cuenta que la mayor parte de las mercaderias decomisadas eran luego compradas por los mismos contrabandistas o miembros de su estructura, bien pudiera tratarse del mecanismo conocido como aforo, al igual que se efectuaba en los almojarifazgos, consistente en la evaluación del valor del artículo por declaración del mercader que lo introducía. Sobre los procedimientos para averiguación de valores fiscales, ver Pulido Bueno, 1., Almojarifazgos y comercio exterior. Op. cit., págs. 96-139.

${ }^{19}$ Los precios de las mercancías confiscadas, en A.G.S., Contaduría del sueldo, $2^{\mathrm{a}}$ serie, legajo 162. Los precios corrientes o de mercado, en Hamilton, E.J., El tesoro americano y la revolución de los precios en España, 1501-1650. Barcelona, 1975. 


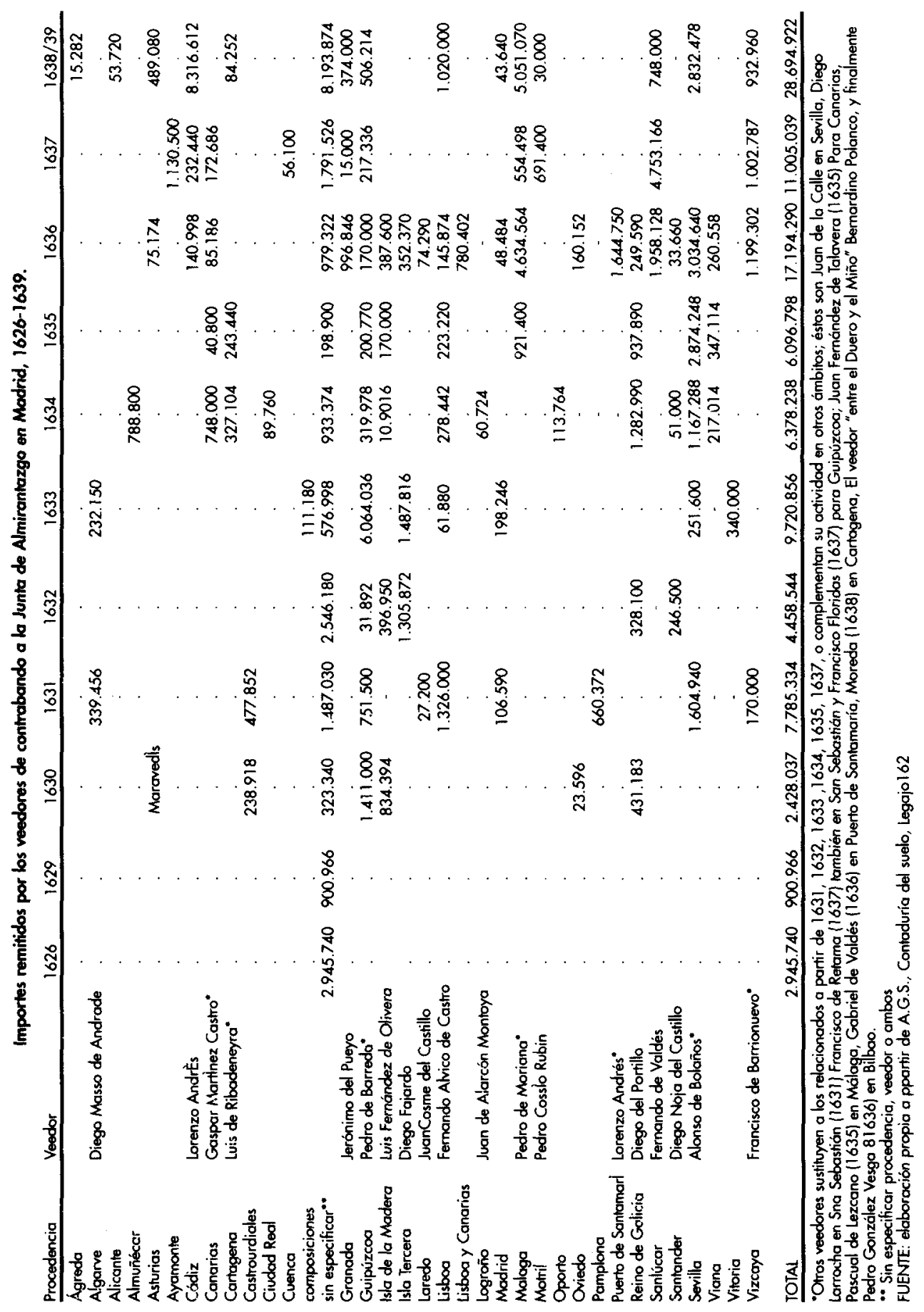


Por estas razones, la cuenta de Francisco de Manzano, que muestra los ingresos percibidos entre los años 1626 y 1639 , únicamente es indicativa si se tiene en cuenta que las cifras que contiene suponen tan sólo un tercio del valor de los bienes de contrabando confiscados, y que los precios de venta de los productos decomisados estuvieron siempre muy por debajo de los que prevalecían en el mercado. De este modo, la suma de dinero que llegó a la Junta, elevada a 97.608.764 maravedís representa tan sólo la punta del iceberg del valor obtenido de las haciendas del contrabando confiscadas durante aquellos 15 años, ya que la cifra pudo bien haber sido cinco o seis veces superior. El siguiente caso ilustra con claridad cuanto se viene diciendo: a fines de 1628 el Almirantazgo se incautó de un cargamento importante de mercancías de contrabando proveniente de Francia, el cual superaba los 100.000 ducados y pertenecía a una conocida red de contrabandistas integrada por conversos portugueses, cuyos representantes eran Francisco Montesinos y Jorge Enríquez. Tras negociar con el Rey y el Consejo de Hacienda una composición, no sin dificultades el Monarca acabó aceptando el donativo de 20.000 ducados y un préstamo de 100 mil ofrecido por los judíos, de cuyas resultas únicamente llegaron a la Junta 500 ducados, los cuales se habían reservado para pagar a los denunciadores de mercancías de contrabando. ${ }^{20}$ Es decir, que de un importante ingreso de 20.000 ducados para la Real Hacienda promovido por el Almirantazgo, tan sólo llegaron a Francisco de Manzano 500 ducados. Un caso opuesto puede encontrarse en 1638, cuando el indulto de 12.000 ducados concedido a Vicente del Campo y otros mercaderes vecinos de Cádiz que habían introducido ropa de contrabando, fue abonado íntegramente, aunque en diferentes partidas, a la Junta de Madrid.

En ocasiones, el receptor recibió el dinero directamente de las personas que compraron los productos confiscados y condenados de contrabando, impidiendo conocer qué porcentaje de esas ventas correspondía a la Real Hacienda, cual al veedor o juez instructor y cual al denunciador, si es que lo había. Este es el caso, como se vio, del importe correspondiente a 26.499 reales que Manzano recibió de los mercaderes flamencos residentes en Madrid, Guillermo de Lovaina y Abraham Lerses, procedente de las 803 libras de clavo de especia que la Junta les habia vendido a 33 reales la libra, y cuyo pago efectuaron mitad al contado y mitad al fiado. Otras veces ocurrió al contrario, al percibir la Junta ingresos en concepto de licencias que se otorgaban para exportar algunos productos, como en 1630 cuando el mercader flamenco Adrian Paez sirvió a Su Majestad con 500 ducados por el permiso que le concedió para "sacar frutos de estos reinos" en cuatro navíos que acababan de llegar a Málaga. Por lo demás, la

\footnotetext{
${ }^{20}$ Véase Belinchón, "Sacar la sustancia del reino". Op. cit. págs. 1.036-1.044. Lo que ingresó la Junta por ese concepto, en A.G.S., Contaduría del sueldo, $2^{\mathrm{a}}$ serie, legajo 162 (año 1629).
} 
contabilidad anual de los contrabandos también es imprecisa, ya que se conoce la fecha en la cual el receptor anotó las partidas que le iban llegando, pero se ignora cuando se produjeron realmente las confiscaciones. También se registran ingresos por conceptos que resultan de lo más pintoresco, como el cargo a favor del Almirantazgo de 12.000 ducados de plata asentado en febrero de 1639, y a pagar por Manuel de Paz, en nombre del Rey, por el dinero que la Junta había prestado al Monarca hasta la llegada de los galeones.

Las cuentas de los representantes del Almirantazgo en Galicia, realizadas para el periodo 1628-1635 por Blas de la Concha, "pagador de la gente de guerra del Reino de Galicia y depositario de los contrabandos de él» reflejan espléndidamente las diferencias existentes entre el valor de lo que se arrebató a los contrabandistas y el dinero que finalmente llegó a la Junta de Madrid. De los 408.424 reales que importaron las haciendas del contrabando aprehendidas y cobradas por el veedor Diego Portillo en Galicia durante el periodo mencionado, se destinaron a la Real Hacienda 159.727, de los cuales tan sólo 87.651 reales llegaron al final a Madrid, a poder de Francisco de Manzano. Bien es verdad que los cuatro navíos procedentes de Hamburgo incluidos en el contrabando de Galicia, nombrados San Miguel, Elector, Aguilanegra y Rey David, fueron condenados sólo en dos terceras partes, quedando la tercera absuelta. ${ }^{21}$ Lo decisivo en todo caso fue que muy poco más de un tercio de lo aprehendido en la costa gallega arribó finalmente a la capital. ${ }^{22}$

\footnotetext{
${ }^{21}$ Lo acontecidn con esos cuatro navíos fue, sin embargo, muy grave, ya que intentaban pasar las mercancías con licencias falsas, siendo en aquellos momentos el comercio con Hamburgo muy fluido. Quizá por esa razón, los cónsules de las naciones flamenca y alemana, residentes en Andalucía, sirvieron a Su Majestad con 33.000 reales por los interesados en las haciendas de esos cuatro buques, "por haberles suplido los defectos de los testimonios con que venian las dichas mercaderías". Un dinero, contabilizado por Manzano en 1639, que el Rey destinó al señor Protonotario para gastos secretos de su servicio. Por otra parte, los registros de la Junta elaborados por Manzano muestran que tanto el veedor de Málaga, Pascual de Lezcano, como el fiscal de la audiencia de Sevilla y juez asesor del Almirantazgo, Juan de la Calle, remitieron a Madrid durante 1636 y 1637 partidas correspondientes a los navíos Rey David y San Miguel por valor de 48.000 reales, la mitad de los cuales resultaba de lo obtenido por las tablas que venían en el Rey David. A.G.S., Contaduría del sueldo, $2^{\mathrm{a}}$ serie, legajo 162.

${ }^{22}$ Las cuentas del contrabando en Galicia, en A.G.S., Contaduría del sueldo, $2^{\mathrm{a}}$ serie, legajo 116.
} 
Cargo del depositario de los bienes del contrabando en Galicia, 1628-1635.

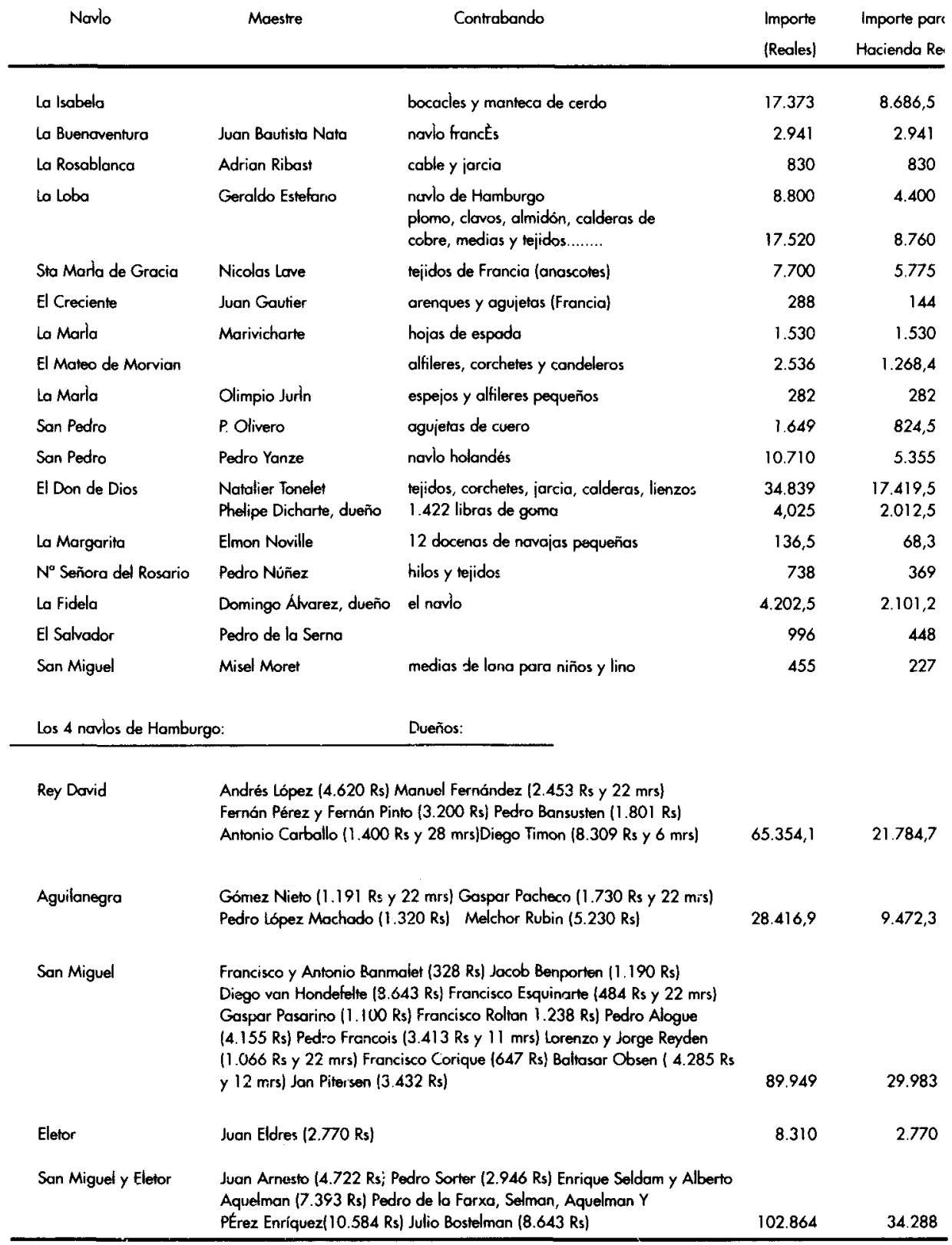

FUENTE: eloboración propia c partir de A.G.S., Contadurla del sueldo, $2^{\text {TM }}$ serie, legajo 116. 
"Relación de las mercaderlas que vinieron en los cuatro navios hamburgueses nombrados San Miguel, Elector, Aguilanegra y Rey David, según consta del mapa que de ellas se ha hecho y el dinero que importa su valor conforme las tasaciones que de ellas se hicieron".

Mercancias

33 piezas de manteles de 20 varos cada una 6 piezas de servilletas de 38 varas cada una

1. 293 mazos de trenzaderas de 12 piezas coda uno*

1. 677 piezas de holandillas

321 piezas de bocacles gordos

49 piezas de bombacles bastos

3. 200 cajas de cerdos para zopateros

5. 426 mazos de cañones para escribir, 100 por mazo

2. 111 libras de latón en vacinillas

1. 991 libras de hilo de alambre

415 docenas y media de servilletas

578 libras de hoja de latón

1. 200 hojas de espada

19 hojas de dagas

62 hojas de espada de esgrimo

100 quintales de azul (tinte)

3. 214 libras de hilo de hierro

1. 968 tablas de manteles

777 piezas de fustanes

59 piezas de bombacles de lustre

23 quintales y 80 libras de estaño en panes

717 libras de cobre amarillo en calderas

1. 712 cuchillos

5 cables de jarcia alquitranada, peso 84,2 quintales

69 quintales y 60 libras de jarcia

9 calderas grandes, 1603 libras

10 barriles de almidûn, 34 quintales y 17 libras de peso

53 piezas de perpetuanas, que llaman ras

71 mazos de alfileres grandes y pequedos

119 piezas de anascotes

1. 814 libras de calderas de latón
Precios

Volor(Reoles)

7 reales lo varo

4. 620

2 reales y 2 mrs. la vara

536,5

1 real y 1 cuartillo la pieza $\quad 19.305$

entre 40 y 44 reales cado pieza $\quad 72.590$

30 reales $\quad 9.630$

33 reales $\quad 1.617$

1 real 3. 200

11 reales el millar $\quad 5.968$

2 reales y $3 / 4$ ia libra $\quad 5.805,2$

entre 7,5 y 8 reales la libra $\quad 15.731,2$

30 reales la docena $\quad 12.465$

3,5 recles la libra $\quad 2.023$

6 reales cada una $\quad$ 7. 200

2 reales cada una $\quad 38$

2 reales cada una $\quad 124$

1,5 reales la libra $\quad 14.998,5$

4 reales cada una $\quad 12.856$

10 reales cada tabla $\quad 19.680$

25 reales la pieza $\quad 19.425$

24 reales cada una $\quad 1.416$

1,5 reales la libra por ser malo 3.570

2 reales la libra $\quad$ 1. 434

3 reales la docena $\quad 428$

8 ducados el quintal $\quad 7.409$

100 reales quintal $\quad 6.960$

3 reales la libra $\quad 6.069$

16 reales la arroba 2.187

50 reales cada una $\quad 2.750$

660

140 reales la piezo $\quad 16.660$

2,5 reales la libra $\quad$ 4. 535

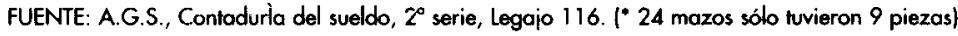

Monta el valor de las dichas mercaderías a los precios referidos 281.890 reales y 31 maravedís de que tocaron a S.M. de su tercia parte en conformidad de la orden de la Real Junta del Almiraniazgo 93.963 reales, que hacen 3.194.763 mrs. Y lo que se carga al pagador de lo que entró en su poder de la parte que tocó a S.M. importa 3.114 .454 mrs. en 16 partidas ... y el resto que falta consiste en las 113 piezas de holandillas gruesas como bocacíes que se remitieron a Madrid a pader del contador Francisco de Manzano como también 533 varas de bayeta de que toca a S.M. la mitad. El lienzo y las calderas que venian en el Rey David se absolvieron. Las cerdas no tuvieron solida y se pudrieron por no ser cosa que se gasta en Galicia. 
Pero basta con mirar la data (los gastos y libramientos) de los veedores para interpretar correctamente el desajuste tan amplio que existía entre el dinero proveniente de las haciendas del contrabando que correspondía a la Real Hacienda, y el que llegaba a la Junta. Sin salir del reino de Galicia, se observa que de los tres navios confiscados hasta fines de 1630 (la Isabela, la Buenaventura y la Rosablanca) se obtuvieron 21.144 reales, de los cuales correspondian a la Real Hacienda 11.000. Como quiera que por orden del gobernador y capitán general del Reino de Galicia, marqués de Espinardo, se pagaron a la hermana del capitán Luis de Camarenas 7.886 reales, y que además se libraron pequeñas cantidades a algunos colaboradores en los embargos, al final sólo llegaron a poder de Francisco de Manzano 3.000 reales. La contabilidad del receptor revela también los múltiples gastos que poco a poco iban mermando sus ingresos, entre los cuales destacaban los pagos por el transporte a Madrid de las mercancias, cuando no se vendían en el punto de origen del embargo, y los costes de conducción y premios del dinero, cuando los abonos se realizaban mediante letras y cartas de pago. Los ejemplos que se ofrecen a continuación no sólo muestran la realidad de las sisas a que se enfrentaban los caudales pertenecientes a la Junta del Almirantazgo en la capital, sino también y sobre todo las tupidas redes mercantiles que operaban durante buena parte del siglo XVII en la Península.

Un conocido asentista de Felipe IV Ilamado Benjamin Ruit, de nacionalidad inglesa pero con naturaleza en España, depositaba en la Junta las cantidades a que él mismo y sus compatriotas eran condenados en los distintos puertos del Norte y del Sur cuando les aprehendían mercancías de contrabando, pero descontando los gastos de conducción del dinero, y a veces otros relativos a los cambios, cuyo montante dependía de si el abono se hacía en plata o en letra con valor en plata. En 1633 abonó ("por letras que sobre él habían dado “) cerca de 70.000 reales procedentes de las confiscaciones del navío El Sacrificio de Abraham, que había sido detenido y condenado en Bilbao. De esas letras el señor Ruit reducía un 8,5 por ciento en concepto de «interés y premio de remitir las cantidades en letra». El precio de la conducción oscilaba entre un tres y un cinco por ciento, dependiendo de quién hiciera los envios: cuando los hacia un funcionario ciel estado, los gastos a duras penas alcanzaban el tres por ciento, cuando los hacía un mercader particular - que además era él mismo quien conducía el dinero por medio de sus depositarios o de depósitos bancarios de los que él era accionista- entonces llegaban fácilmente al cinco por 100. En 1634 Juan de la Calle, fiscal de la Audiencia de Sevilla y juez asesor del Almirantazgo, envió a Madrid 27.500 reales de las condenas de los navíos San Maló, San Vicente y San Pedro, deduciendo de esa cifra el 3,2 por ciento (882 reales) por gastos de conducción. Sin embargo, el citado Ruit, por una letra de 5.715 reales que sobre él había dado Ricardo Suit desde Sevilla en 1634 , se dedujo el 4,75 por ciento ( 285 reales). 
Finalmente, cabe reflejar también algunos casos de fraude detectados en la contabilidad, los cuales mermaron asimismo la cuenta de resultados, aunque hay que tener presente que estos casos no muestran únicamente el hecho mismo de las defraudaciones, sino también que se actuaba contra ellas. El propio Francisco de Manzano hubo de enfrentarse a varios alcances, de los cuales logró salir indemne: en el cargo del periodo 1625-1631 tuvo un alcance de 3.616 reales; en el comprendido entre algunos meses de 1633 y algunos otros de 1634, se le descubrió otro desfase en sus cuentas de 8.144 reales. ${ }^{23}$ El arrendador de los puertos secos del Norte, Juan de Zabalza (el tablajero de Navarra, conocido contrabandista de Pamplona) además de estar siempre bajo sospecha de fomentar el contrabando de portugueses, ingleses y holandeses, así como la saca de oro y plata a Bayona y San Juan de Luz, fue en más de una ocasión condenado a pagar por introducir mercaderías de contrabando: en 1631 le confiscaron 11.907 reales, de los cuales tres cuartas partes fueron a la Real Hacienda. En 1636 fue don Jerónimo Pacheco, oidor de Valladolid y ex-gobernador de Asturias, quien se vio obligado a pagar 2.321 reales por el alcance que se le descubrió en sus cuentas de cuando el contrabando del Principado estuvo a su cargo. Del mismo modo, don Martín Nieto Trejo, alcalde de la Chancillería de Granada, se vio obligado a pagar 7.614 reales debido a los alcances que tuvo un depositario nombrado por él, detectados en Málaga y Antequera. El Mercader granadino Antonio Montañés fue condenado en reiteradas ocasiones debido a las prácticas tan heterodoxas que realizaba en relación con los bienes confiscados: en 1639 se le condenó a pagar 11.000 reales por disponer de diferentes mercaderías de contrabando que le habian sido aprehendidas, y que se depositaron jen él mismo! sin orden ni licencia del Almirantazgo.

En síntesis, la cifra de 260.000 ducados depositada en manos del receptor de la Junta entre 1626 y 1639 , equivalente a cerca de un tercio del valor de las confiscaciones efectuadas en los puertos de la Península e islas Canarias, Azores y archipiélago de Madeira, exceptuando Cataluña y Reino de Valencia, muestra algunas luces y sombras sobre la lucha de la Monarquía contra el contrabando iniciada tras la reanudación del conflicto con las Provincias Unidas, las hostilidades con Inglaterra entre 1625 y 1630, y la ruptura con Francia en 1635. Desde luego, la suma podria haberse incrementado sin dificultad algunos puntos si se hubiesen vendido los bienes confiscados a precios aproximados a los corrientes. También podría haber aumentado si se hubiese añadido a ella el valor de las mercancías decomisadas que en lugar de ser tasadas y vendidas fueron recuperadas por sus consignatarios previo pago de un indulto o de una composición -especialmente a partir de 1635- ya que en algunos casos los

\footnotetext{
${ }^{23}$ A.G.S., Contaduría Mayor de Cuentas, legajo 400.
} 
importes abonados por estos conceptos fueron ridículos. En 1636 Enrique de Andrade pagó 25.767 reales por composición de los 33 fardos de ruanes que le habian aprehendido en Andalucía en un navio llamado San Jorge, sin embargo ese mismo año Juan y Gaspar Pasarinos desembolsaron 1.800 reales por un solo fardo de ruanes, es decir, el doble de dinero por fardo, a pesar de tratarse de una composición negociada con el mismo juez, Juan de la Calle. Una vez iniciada la represalia contra los franceses en 1635 , mucha ropa de contrabando que llegó a Andalucía del país vecino se introdujo en los mercados de la península mediante el pago de composiciones o indultos, como puede apreciarse en el apéndice documental en este mismo estudio.

\subsection{La data.}

La práctica totalidad de los ingresos que Francisco de Manzano registró entre 1625 y 1632 fue a parar a manos de los "señores" y el personal de la Junta, en concepto de propinas, luminarias, ayudas de costa y salarios. Muy escasas partidas se destinaron a retribuir la parte correspondiente a los denunciadores, porque ésta se solía liquidar en los mismos puertos y a instancias de los veedores. No obstante, el receptor de la institución pagó algunas partidas correspondientes a denunciadores. A Juan Rodríguez Temudo, denunciador de Jarish Banderley, cuyo navio y carga de trigo habían sido confiscados en 1626, le benefició con 300.000 maravedís, aunque el importe resultante de aquel decomiso se había elevado a 2.945.740 maravedís. O cuando liquidó a Martín de Yepes los 6.624 reales que constituían la cuarta parte de la especia de clavo que fue confiscada en una presa efectuada en 1629. Una cantidad más importante fue la que ganó el denunciador Juan Ortiz de Uriarte, cuando en 1633 la Junta mandó pagar al susodicho 27.500 reales procedentes de los 175.470 en que se había valuado el navío "El sacrificio de Abraham", procedente de Londres. Otras partidas de menor cuantía se libraron para sufragar gastos propios de la Junta, o incluso gastos de transporte de bienes embargados y documentos, como la relativa a 108 reales que se pagaron al arriero que desde Bilbao transportó en 1627 las 10 arrobas y 18 libras de papeles del contrabando, a razón de nueve reales por arroba. 


\section{Pagos y salarios de la Junta del Almirantazgo, 1625-1632}

\begin{tabular}{|c|c|c|}
\hline Receptor & Concepto & Maravedis \\
\hline Sr. Brizuela, Obispo, Consejo de Flondes & propinas, luminarias, ayudas de costa y salarios & 414.000 \\
\hline \multicolumn{3}{|l|}{ Baltasar Gilimón de la Mota } \\
\hline (presidente Consejo de Hacienda) & propinas, luminarias, ayudas de costa y salarios & 414.000 \\
\hline Diego de Mejla (coniador Mayor) & propinas, luminarias, ayudas de costa y salarios & 414.000 \\
\hline Juan de Pedroso & propinas, luminarias, ayudas de costa y salarios & 414.000 \\
\hline Mendo de la Mota & propinas, luminarias, ayudas de costa y salarios & 414.000 \\
\hline Antonio Cornero (secretario de la Junto) & propinas, luminarias, ayudas de costa y salarios & 420.000 \\
\hline Juan Bautista Sáez (oficial secretarla) & propinas, luminarias, ayudas de costa y salarios & 82.720 \\
\hline Adom de Rogibal (portero de la Junta) & propinos, luminarias, oyudas de costa y salarios & 127.466 \\
\hline Francisco Manzano (receptor de la Junta) & propinas, luminarias, ayudas de costa y salarios & 239.700 \\
\hline Juan Novarro (oficial segundo secretarla) & propinas, luminarias, ayudas de costa y salarios & 289.860 \\
\hline Licenciado Girón (relator de la Junta) & propinas, luminarias, ayudas de costa y salarios & 80.650 \\
\hline Lucas Fern.ndez (fiscal de la Junta) & propinas, luminarias, ayudas de costa y salarios & 166.380 \\
\hline Cristóbal de Castroverde (alguacil Junta) & propinas, luminarias, ayudas de costa y salarios & 27.750 \\
\hline Joseph de Enciso (oficial mayor) & propinas, luminarias, oyudas de costa y salarios & 261.500 \\
\hline Juan Varela (escribano de la Junta) & propinas, luminarias, ayudas de costa y salarios & 3.696 \\
\hline Marqués de Leganés & propina y luminarias de la fiesta de toros & 350.000 \\
\hline Diego del Corral & propina y luminarias de la fiesta de toros & 350.000 \\
\hline Marqués de Castrofuerte & propina y luminarias de la fiesta de toros & 350.000 \\
\hline Francisaco de Tejada & propina y luminarias de la fiesta de toros & 350.000 \\
\hline Jerónimo de Villonueva & propina y luminarias de la fiesta de toros & 350.000 \\
\hline Mendo de la Mota & propina y luminarias de la fiesta de toros & 350.000 \\
\hline Pedro Coloma & propina y luminarias de la fiesta de toros & 350.000 \\
\hline Francisco Gómez Laspirilla & propina y luminorias de la fiesta de toros & 170.000 \\
\hline Señores de la Junta y ministros de ella & propina y luminarias de la fiesta de toros & 8.661 .730 \\
\hline Luis Ponce (olguacil) & & 44.400 \\
\hline Pedro de Medrono & & 34.000 \\
\hline Pascual de Azpeitia (agente fiscal de la Junta) & & 86.750 \\
\hline Domingo Palacios (librero) & & 60.766 \\
\hline Adan Brinzano (juez contrabando en Madrid) & & 136.000 \\
\hline Luis de Habloos (Consejo de guerra) & propinas que se le deblan del Consejo & 459.000 \\
\hline Pedro Barreda (ex-veedor contrabando Algarve) & & 304.810 \\
\hline \multicolumn{3}{|l|}{ Pedro Romlmez de Arellano } \\
\hline (veedor del contrabando en Cartagena) & & 150.000 \\
\hline \multirow[t]{2}{*}{ viuda del juez del contrabando de Madrid } & & 136.000 \\
\hline & Gostos varios de la Junta & 416.538 \\
\hline \multirow[t]{2}{*}{ a diferentes personas } & pọr denunciación de mercanclas de contrabndo & 832.973 \\
\hline & por otros libramientos ordenados por Su Majestad & 3.201 .160 \\
\hline Total. & $\ldots \ldots$ & 20.913 .849 \\
\hline
\end{tabular}

FUENTE: elaboración propia a partir de A.G.S., Contadurla del sueldo, $2^{\circ}$ serie, legajo 162. 
En ocasiones se registraron libramientos de la Junta para ayuda de costa de los veedores, con independencia de que éstos se encontrasen más que bien remunerados. A Diego del Portillo, veedor en la Coruña, le concedieron 50.000 maravedís en septiembre de 1630 en consideración de los viajes que habia hecho para visitar los puertos. Otras veces se libraba dinero de la Junta para efectos sin relación alguna con el contrabando; este es el caso de la partida de 13.500 reales que se pagó a Luis de Hablaos, a quien el Consejo de Guerra debía este dinero y se decidió tomarlo de las haciendas del contrabando, acaso por ser el único lugar que disponía de liquidez en ese momento. Otros libramientos, incluso muy grandes, se efectuaron por conceptos que bien podían rozar lo pintoresco, como el relativo a los 6.000 ducados de vellón a proceder del contrabando de Canarias con que se benefició a doña Ana Bazán, dama de la Reina, para ayudar a concluir su casamiento. Aunque no está claro que acabara cobrándolo del todo, ya que en diciembre de 1636 tan sólo se le habían pagado 2.000 ducados.

De los libramientos y gastos de la Junta recogidos en el cuadro antecedente se desprende que la Real Hacienda no se benefició, al menos directamente, de los decomisos que por contrabando efectuaron los veedores y agentes dependientes del organismo. No se puede concluir, en consecuencia, que la Monarquía tratase en este periodo de fiscalizar el contrabando. Más bien parece que trataba de combatirlo para conseguir el bloqueo efectivo del comercio enemigo y fiscalizar mejor las licencias especiales, como más adelante se observará. Si bien, tras analizar algunas de las redes de contrabandistas que operaban en el ámbito de la Monarquía Hispánica en la primera mitad de la centuria del Seiscientos, también da la sensación de que no se pretende acabar del todo con ellas, sino más bien tenerlas bajo control y utilizarlas en caso de necesidad de abastos y otros recursos.

\section{LAS REDES DEDICADAS AL CONTRABANDO: PORTUGUESES, INGLESES Y FRANCESES.}

Si el balance económico de la Junta del Almirantazgo ofrece a los historiadores un panorama de luces y sombras, habida cuenta de que la institución no recaudó todo lo que debía, y que la Real Hacienda no apuró en ningún momento la fiscalización del comercio ilegal, ni se benefició directamente de él, la actividad ilevada a cabo por las redes de contrabandistas no parece que preocupase en extremo al gobierno de Felipe IV. Parece que más que el contrabando, lo que preocupaba al gobierno de la Monarquía era tenerlo controlado. Se ordenaron investigaciones para conocer el alcance del fenómeno, y se obtuvo un conocimiento profundo del mismo, sin embargo no se castigó a los contrabandistas, sino que se les dejó hacer, 
y ello a pesar de que entre 1635 y 1660 el delito de contrabando se equiparó en repetidas ocasiones al de Lesa Majestad, que acarreaba la pena de muerte a sus autores. Ni siquiera ante hechos tan lesivos para la Real Hacienda como la introducción de ingentes cantidades de moneda de vellón falsificada - cerca de 39 millones de ducados en los 15 años que transcurren entre 1606 y 1620 - se administró la justicia debida a sus autores, dirigidos por el converso portugués Juan Núñez de Saravia, cuyos delitos fueron esclarecidos y probados por espías al servicio del Rey de España, pero jamás castigados. ${ }^{24}$ Su descendiente Enrique Núñez de Saravia practicaba el contrabando con toda tranquilidad en 1638, cuando le fueron aprehendidos 7 fardos de bocacíes que tan solo se tasaron en 600 reales.

En otra ocasión acaecida a comienzos de 1625, la justicia consiguió abortar un descamino de 128.679 reales y cinco barras de plata que dirigían a un barco francés en Sanlúcar de Barrameda. El Consejo de Guerra comisionó a Juan Pedroso para que investigara ese delito y otros que se estaban produciendo en la zona, cuyas averiguaciones habían sido realizadas por el alcalde de Casa y Corte Miguel de Cárdenas. La nota del Consejo de Guerra terminaba mandando a Pedroso a que avocara las causas que hubiese pendientes tocantes a descaminos y saca de metales, cuyo conocimiento se traspasaba en exclusiva a los consejos de Guerra y Justicia, pero nada se decía en el oficio del castigo a los culpables. ${ }^{25}$

El gobierno económico de la Monarquía disponía de información suficiente acerca de todos los asuntos relacionados con el contrabando y el comercio fraudulento, y cuando demandada conocimientos más puntuales sobre el fenómeno encargaba sus propias investigaciones. En 1623 los resultados de una de ellas, ordenada por el Consejo de Hacienda sobre la introducción de contrabando rebelde desde Bayona y San Juan de Luz, vía Navarra y puertos secos de Castilla, desveló la llegada frecuente de navíos holandeses a dichos puertos - 30 barcos entre agosto de 1621 hasta noviembre de 1622 con mercancias cuyo valor podría elevarse hasta 800 mil ducados - cuyas cargas eran remitidas desde Holanda por judíos portugueses, siendo después introducidas con pasaportes falsos en Castilla. Nicolas Broens constató que la Junta del Almirantazgo trabajaba con informes que estimaban entre dos y tres millones de ducados el contrabando que los holandeses introducían en España hacia 1630.

La actividad de una de las redes más dinámicas de contrabandistas, integrada por conversos portugueses, ha sido recientemente documentada por Bernardo José López Belinchón, en cuyo trabajo se observa bien el alcance

\footnotetext{
${ }^{24}$ Vease el interesante artículo de Carrasco Vázquez, J., "Contrabando, moneda y espionaje (el negocio del veilón: 1606-1620)", HISPANIA, 197 (1997) págs. 1.081-1.105.

${ }^{25}$ A.G.S., Guerra Antigua (Guerra y Marina), Legajo 917.
} 
de esta trama, su operativa fraudulenta, sus protagonistas y sus conexiones e influencias para desarrollar este comercio ilícito pero muy lucrativo. ${ }^{26}$ Muchos integrantes de este grupo de contrabandistas (Manuel Cortizos, Enrique Méndez, Jerónimo de Fonseca, Fernando Montesinos, Jorge Enríquez...) eran exportadores de lana en San Sebastián, Bilbao o Santander, o arrendadores de rentas y estancos, y sin embargo pasaban el contrabando a través de las aduanas y puertos secos del Norte, que ellos mismos custodiaban, o con cuyos arrendadores habían establecido fuertes vínculos, como con el portugués Juan Núñez Vega, arrendador de los puertos secos altos, de la raya de Navarra y Aragón, o con Juan Zabalza, arrendador de las Tablas de Navarra, quien esperaba las mercancías de Francia que llegaban por Irún, Maya y Burguete, para introducirlas sin costes - por su calidad de Navarro-y luego despacharlas por Ágreda y Cervera. Los receptores de esta red se encontraban repartidos entre Segovia, Burgos, Valladolid y Madrid.

El examen de los registros de la Junta del Almirantazgo desvela importantes aspectos de la operativa de estas tramas, integradas asimismo por ingleses $y$ franceses, $y$ en menor medida por flamencos $y$ alemanes, pero sobre todo revela el escaso interés de la Monarquía en condenar a las personas que realizaban el comercio ilegal: sólo se condenaban las mercancías, y en contadas ocasiones al mercader, aunque mediante el pago de indultos o composiciones lograba siempre salir indemne. En 1632 la Junta confiscó la goma que habian introducido los portugueses Jerónimo de Fonseca (arrendador del estanco de la goma) Simón Méndez, Francisco R. Enríquez, Bartolomé Febos, Francisco Dacosta y Juan Pérez de Veroiz, valuada en un millón y medio de maravedís; si bien, muchos de estos hombres o sus parientes aparecieron inscritos durante los siguientes años en los registros de Francisco de Manzano. Al Portugués Pedro Fernández Pato le confiscó la Junta 113.560 maravedís por diferentes mercancias que había introducido de contrabando, y en 1634 le volvió a condenar en Viana una carga de bayetas y otras mercaderías por valor de 217.014 maravedís. Los Ingleses Abraham Ruter y Arthur Orichur fueron embargados en Bilbao, por valor de 400 mil maravedís, tras intentar introducir en 1636 unos cargamentos de alfileres y ropa de Francia; en 1637 sorprendieron de nuevo a Orichur comprando lanas de contrabando también en Bilbao, mientras su compatriota Ruter fue detenido al año siguiente tratando de introducir 130 fardos de lencería de Francia. Al conocido contrabandista portugués Jorge Enriquez se le confiscaron en 1633 poco más de 700 reales por contrabando, y cinco años más tarde le volvieron a sorprender con mercancías introducidas ilícitamente. Antonio Montañés fue condenado en

\footnotetext{
${ }^{26}$ Artículo citado en nota número 19. Su experiencia como exportadores de lana queda acreditada en Israel, J., "Spanish Wool Exports and the European Economy, 1610-40" The Economic History Review 2 (1980) págs. 193-211.
} 
reiteradas ocasiones durante los años 1636,37 y 38 por diferentes excesos en relación con el comercio ilegal en la costa Oriental de Andalucía. Muchos de estos mercaderes dedicados al comercio legal e ilegal acabaron siendo buenos prestamistas de Felipe IV.

Bien es verdad que debido a lo intrincado de las formas de llevar a cabo sus negocios, no resultaba fácil combatir la actividad ilegal de estas mafias. La conexión inglesa, integrada por conocidos comerciantes como Guillermo Pauley, Duarte Brandon, Ricardo Suit, Petruen Cuaton, Jorge Inqueldo, Arthur Orichur, Abraham Ruter, Nicolas Soanes, Esteban Stoques, Thomas Lebreton, Marmaduque Ramdom y otros, se había especializado en la introducción de mercaderías tanto de Inglaterra como de Francia por los puertos del Norte (Bilbao, San Sebastián o incluso Santander) por Portugal y sus islas, y ocasionalmente también por Andalucía y Tenerife. Contaba este grupo con el apoyo de un importante hombre de negocios residente en Madrid, llamado Benjamín Ruit. El señor Ruit pagaba en Madrid las letras que contrabandistas ingleses como Pauley daban sobre él para comprar mercancías confiscadas, o recomprar las que a ellos mismos les habían embargado. En 1634 Guillermo Pauley llegó a un acuerdo con el veedor de San Sebastián, Diego Larrocha, para comprar por 4.816 reales las 3.853 libras de goma que habían confiscado a su compatriota inglés Petruen Cuaton. Un año después, el mismo Pauley rescató, por el precio de 1.580 reales, los paños, antepuertas y carpetas que habían confiscado en Andalucía a otro compatriota suyo llamado Thomas Boom.

En otras ocasiones estos ingleses compraban las mercancías confiscadas a mercaderes de distintas nacionalidades: Ricardo Suit y Nicolas Soanes adquirieron en 1635 las piezas de Olanes que habían embargado en Sevilla a Guiomar Baudens, las cuales pagaron mediante una letra dada sobre Benjamín Ruit. El mismo Ricardo Suit compró por 7.618 reales las cien piezas de lienzo confiscadas a los mercaderes Diego Flet y Jacques Hanlon aquel mismo año, pagando también con letras sobre Benjamín Ruit. Pero no siempre actuaban en los límites de la ley, sino que los traspasaban cuando podían; Thomas Lebreton fue condenado en apelación por la Junta al pago de 12.000 reales por haber descargado en el puerto de San Sebastián lienzos y otras mercancias por la noche y sin permiso del veedor, que en aquellos momentos era Francisco de Retama, conocido memorialista sobre el comercio exterior. Otra ocasión extrema acaecida al año siguiente fue protagonizada por Ricardo Suit y otros consortes por introducir y ocultar en Sanlúcar 112 fardos de lienzos de Francia, lo cual les costó verse incursos en una causa criminal, que lograrían eludir al poco mediante el pago de 66.000 reales de plata doble en concepto de indulto.

Los portugueses gozaban de mayor experiencia en el comercio ilícito y de plataformas mucho más depuradas que las que podían alzar ingleses o 
franceses para desarrollar sus actividades fraudulentas. Por añadidura, los múltiples vínculos familiares existentes entre ellos lograban generar una enorme confusión sobre su verdadera identidad. Trabajaban, como se ha dicho, por el Norte de la Península, pero el contrabando de Portugal también era de su incumbencia, y nunca abandonaron otras áreas calientes como Andalucía y las Islas Canarias. Simón Sanz, Gómez Pardo, Fernández Pato, Núñez Peña, Núñez Soto, Fonseca, Méndez, Enríquez, Febos, Olivera, Pereira, de Andrade y muchos otros apellidos más constituían una verdadera red de contrabandistas, cuya actividad ilegal introduciendo mercancías de contrabando y sacando moneda de oro y plata, disimulaban con sus negocios lícitos de exportación e importación, de arriendos de aduanas y estancos, de compras de licencias y permisiones de comercio, y de préstamos al Rey una vez habían logrado acumular importantes capitales. Como los ingleses, adquiríarı ellos mismos las mercancias que no habian logrado introducir ilegalmente al haber sido aprehendidas antes por los veedores. Antonio Enríquez compró en 1635 los cinco fardos de alfileres que habian confiscado en San Sebastián a Juan Pérez de Veroiz.

Enrique de Andrade consiguió en 1636 llegar a un arreglo de composición con la Junta mediante el cual le devolvían los 33 fardos de ruanes que le habían aprehendido en el navío San Jorge a cambio de 25.767 reales de vellón. En el mismo navio también habían llegado mercaderías consignadas al inglés Ricardo Suit, las cuales se valuaron en 7.897 reales. Todos estos ejemplos muestran que la Junta se preocupaba más por controlar lo que se introducía en la Península que por lo que se sacaba de ella, pero también existen condenas en este último sentido. El conocido Jerónimo de Fonseca, residente en Lisboa, fue condenado a pagar 4.000 ducados en 1636 por dos fianzas que había hecho, una para Giraldo Nicolás, maestre del navio el Conde Denele, y la otra para Reinel Simon, maestre del navío el Sol Amarillo, quienes se habian comprometido a llevar a países amigos las mercancías cargadas en sus barcos, cosa que no cumplieron; si bien, Fonseca apeló a la Junta y ésta resolvió moderar la condena a la mitad.

Al parecer, cuando en 1643 cayó Olivares del gobierno y se nombró como Inquisidor General a Arce y Reinoso, toda la comunidad de conversos portugueses comenzó a ser perseguida con mayor insistencia que bajo el mandato del Conde-Duque. ${ }^{27}$ La configuración y actividad de las redes dedicadas al contrabando, como la propia documentación de la Junta permite entrever, obedecía al devenir de los acontecimientos más relevantes de la política exterior. Desde la fundación del Almirantazgo hasta 1635, el contrabando estuvo dominado por los conversos portugueses, que introducian las manufacturas y pertrechos navales que hasta 1621 transporta-

${ }^{27}$ Boyajian, Portuguese bankers and the court of Spain, 1626-1650. New Brunswick, 1983. 
ban los holandeses; lo hacían vía Francia o vía Portugal fundamentalmente. En esta misma época no era extraño encontrar múltiples contrabandistas ingleses, en especial entre 1625 y 1630, ya que su comercio con España había quedado interrumpido tras los eventos acaecidos en 1625 . Después de 1635 se siguió encontrando ingleses, pero ahora dedicados al contrabando de mercancías de Francia. Por el contrario, tras la ruptura con el Cristianísimo en 1635, los portugueses disminuyeron sensiblemente su presencia, al tiempo que la ganaban franceses, españoles y un puñado de flamencos. Entre los primeros destacaban Joan Folinque y Miguel Galle, Diego Lermite, Pedro Betat, Pedro Potruit, Giraldo Laurische, Lanfran David, Marcos Marinat, Joseph Piller.

Como se desprende del material estadístico presentado en este trabajo, los lugares que registraban mayor actividad de contrabando eran Guipúzcoa, y en menor medida Bilbao y Reino de Galicia en el Norte; Portugal por Lisboa, Algarve y Viana, pero muy especialmente por isla de la Madera e isla Tercera; Canarias, y desde luego Andalucía, sobre todo a partir de 1635. Los productos y manufacturas que se introducian fraudulentamente fueron los determinados tradicionalmente por la demanda peninsular. De Francia se introducian ruanes, creas y todo tipo de lienzos crudos de distintos nombres y lugares, gomas, resinas, papel de Marsella, alfileres, tijeras, estuches, tornillos, tenazas, martillos, palas de madera, algodón hilado, y otras mercaderías como peines, espejos o dedales. De Inglaterra se importaban paños, bayetas, perpetuanas, bombasíes, picotillos, medias de lana, plomo, estaño, becerros, y otros géneros elaborados con diferentes metales. De Holanda, al igual que de Flandes, por ser las manufacturas trabajadas de la misma forma, se traían olandas, olanes, esterlines, terciopelos y diferentes manufacturas textiles. Finalmente, aunque Alemania y las ciudades de la Hansa gozaban de libertad para comerciar con España, muchas manufacturas de plomo, estaño, acero, como hojas de espada y dagas, alfileres, cubillos, tenazas, navajas, tornillos, sierras, corchetes, latón en rollo, y otros productos textiles como bombasíes o gamuzas, fueron declarados de contrabando al ser transportados en barcos enemigos, o transportar los barcos hanseáticos mercancías del adversario.

\section{LAS LICENCIAS ESPECIALES O «PERMISIONES» PARA INTRODUCIR MERCANCIAS DE CONTRABANDO.}

Como se apuntó al inicio de este artículo, la necesidad de productos fabricados o transportados por el enemigo imposibilitó el cierre hermético de los mercados de la Monarquía. A comienzos del decenio 1620-30 resultaba todavía muy difícil prescindir del transporte holandés, especialmente el relacionado con ciertos productos destinados a la construcción naval, 
por eso aunque el comercio con las provincias rebeldes estaba absolutamente prohibido, en marzo de 1625 el Consejo de Guerra comisionó a Juan Pedroso para que asentase con el Almirantazgo de Sevilla la introducción de 12 navíos holandeses con pólvora, jarcia, árboles, tablazón, alquitranes y plomo «permitiéndoles por esta vez que hagan la conducción de ellas por navíos fabricados en las islas de Holanda y Zelanda, como no sean holandeses los dueños de los dichos navíos, ni naveguen ni tengan parte en ellos". Seis buques habian de traer árboles, tablazón y madera, los restantes vendrían con pólvora, jarcia, cuerda, plomo, alquitranes, pacajes y otros aprestos de barcos, asi como con buenas cantidades de cobre. ${ }^{28}$ Se observa así que el inicio mismo del Almirantazgo, creado para combatir sobre todo el comercio holandés, y que incluía la construcción de 24 navíos de guerra, comenzaba dependiendo de aquel a quien se quería doblegar.

La cuestión de las licencias se reveló entonces contradictoria. Las permisiones para introducir mercancías de contrabando evidenciaron la necesidad de productos manufacturados o transportados por los enemigos, cuyo desabastecimiento se producía precisamente a consecuencia de las prohibiciones que se dictaban para comerciar con ellos. Pero estos problemas no se tomaron a la ligera, sino que se analizaron debidamente en los consejos de Estado y Hacienda. Una lección que se pudo obtener del análisis de esos contratiempos fue que, más que las licencias en sí, los inconvenientes surgían del uso y abuso que se hacía de ellas, y de la cantidad que se otorgaba, porque como reconocía el Consejo de Hacienda, las licencias se daban sólo "para reparo de mayores necesidades» que la de impedir el comercio enemigo. Y no les faltaba razón a quienes así pensaban dentro del citado órgano: muchos beneficiarios de estas licencias especiales aparecieron registrados en más de una ocasión en la lista negra del contrabando. Pero antes de dar paso a esas discusiones llenas de contenido en la cumbre de los aparatos de estado, veamos el alcance real de estas permisiones.

En septiembre de 1628 el Consejo de Estado concedió al mercader flamenco Adrian Paez una licencia, previo pago de 60.000 escudos, para introducir mercancias por valor de un millón de escudos "de a 20 reales", con la condición de que dos tercios de los cuales habían de ser en municiones, bastimentos y pertrechos para las armadas reales. Además, en esta ocasión se autorizó el empleo de buques enemigos para los pertrechos y municiones. El Consejo de Hacienda reprobó la medida por el mal ejemplo que daba a los naturales, argumentando que les disuadía de producir pertrechos de guerra cuando aquí en España se daban en abundancia. Se lamentaba también de que al venir transportados en barcos enemi-

${ }^{28}$ A.G.S., Guerra Antigua (Guerra y Marina), Legajo 917. (Sin foliar). Sobre la importancia para España del transporte holandés, puede verse ISRAEL, J., "Spanish Wool Exports». Op. cit. 
gos, éstos aprovecharían para espiar nuestros puertos. Por añadidura, Hacienda estimaba que el presupuesto que tenía hecho Adrian Paez era de un millón de escudos de a diez reales, por lo que su contribución debería ser al menos de 200.000 ducados.29 Años más tarde, escudándose en la necesidad de dinero que existía en Cartagena para el sustento y embarcación de la gente de guerra que iba a ser transportada a Italia, Felipe IV dio comisión en noviembre de 1638 a don Luis Villagutierre, miembro del Consejo y oidor en la Chancillería de Valladolid, para que concediera licencias por valor de $\mathbf{1 5 0 . 0 0 0}$ ducados que permitieran traer a Castilla manufacturas francesas y alimentos, especialmente ropa y bacalao.

\footnotetext{
${ }^{29}$ A.H.N., Consejos, legajo 4.424 (215).
} 
La Junta de franceses, relación de las licencias y permisiones que se han dado hasto el dìa de hoy a diferentes personas para introducir mercanclas de fóbrica de francia, años 1636, 1637 y 1638.

\begin{tabular}{|c|c|c|}
\hline Titulares de las licencias & Permisión & Intereses \\
\hline & (ducados) & (ducados) \\
\hline Bernardo Rodrilguez y Julio Pérez (Sevilla) & 12.000 & 1,440 \\
\hline Juan Lorenzo Rato (Cartogena) & 10.000 & 1.000 \\
\hline Martin Ladrón de Guevara y Diego Cardoso" & 350.000 & 35.000 \\
\hline Martin de Longares & 50.000 & 6.000 \\
\hline Vicente del Campo y otros vecinos de Cádiz & 340.000 & 40.800 \\
\hline Jorge de Acosta & 6.000 & 720 \\
\hline Juan Lineta & 6.000 & 720 \\
\hline Bartolomé Scoto & 10.000 & 1.200 \\
\hline Froncisco de Lineta & 10.000 & 1.200 \\
\hline Baliasar de Padilla & 4.000 & 480 \\
\hline Diferentes personas de Sevilla & 200.000 & 30.000 \\
\hline Alonso de Sierro y otros & 91.000 & 10.920 \\
\hline Antonio Montoñés & 50.000 & 6.000 \\
\hline Alfonso Cardoso & 50.000 & 5.000 \\
\hline Benjamin Ruit & 950.000 & 65.000 \\
\hline Bartolomé Febo & 100.000 & 10.000 \\
\hline Blas de la Peña, Pedro Alogue y otros & 50.000 & 6.000 \\
\hline Francisco Gómez de Torres y otros & 721.000 & 86.520 \\
\hline Gaspar de Toledo & 20.000 & 2.000 \\
\hline Gerónimo de Fonseca y Pablo de Saravia & 160.000 & 10.000 \\
\hline Hombres de negocio de Sanl car & 100.000 & 15.000 \\
\hline Jorge Inqueldo & 150.000 & 15.000 \\
\hline Juan Diaz Jiménez & 80.000 & 8.000 \\
\hline Juan Ventura Tirado & 20.000 & 2.400 \\
\hline Miguel de C.ceres & 36.000 & 4.320 \\
\hline Nicolás de Peñalba & 20.000 & 2.000 \\
\hline Nicolás fronchot & 50.000 & 0 \\
\hline Nicolás Barresbique & 7.000 & 840 \\
\hline Pedro de Miranda & 35.000 & 3.500 \\
\hline Roberto Chan y otros & 240.000 & 28.800 \\
\hline Vicente del Campo & 61.180 & 6.016 \\
\hline Lo que montan las licencias para intraducir Mercanclas de Francia & & 4.388.0 \\
\hline Lo que ha tenido de beneficio a fovor de Su Majestad & & 438.87 \\
\hline
\end{tabular}

A.G.S., Contaduría del sueldo, $2^{\circ}$ serie, legajo 159. 
Como se desprende del cuadro antecedente, otras muchas licencias se concedieron en el transcurso de todos aquellos años, en especial entre 1636 y 1643. El mercader inglés Benjamin Ruit, el mismo que financiaba las actividades lícitas e ilícitas de algunos compatriotas suyos en materia de contrabando, además de realizar asientos con el rey, obtuvo entre julio de 1636 y octubre de 1638 licencias por valor de 950.000 ducados para introducir mercaderías, bastimentos y pertrechos de Francia a cambio de 65.000 ducados, y a condición de que no se transportasen en navíos franceses ni por gente de aquel reino. En los tres años que transcurren entre 1636 y 1638 se concedieron permisiones a otros comerciantes y hombres de negocios, entre los cuales muchos habían participado ostensiblemente en actividades de contrabando y comercio fraudulento, como Vicente del Campo, del comercio de Cádiz, Antonio Montañés, del de Granada; o los conversos portugueses Bartolomé Febo, Jerónimo de Fonseca o Pablo de Saravia. También había sido condenado el Flamenco Jorge Inqueldo, lo que no le impidió hacerse con una licencia de 150.000 ducados. Gaspar de Toledo, a quien se concedió una de 20.000 ducados para introducir mercancías de contrabando de Francia, acabó cediéndola a Benjamin Ruit. En suma, 4.388.000 ducados en licencias constituian una cantidad demasiado elevada que impedía interrumpir el flujo comercial con Francia, sobre todo si se tiene en cuenta que hacia 1628 sólo las importaciones francesas de lienzos de algodón, según el embajador del Rey Cristianísimo, alcanzaban los cinco millones de escudos de oro, resultantes de los 15 millones de libras anuales de esos tejidos que entraban principalmente por Sanlúcar, Cádiz y Sevilla. Pero también es cierto que los 438.000 ducados que de ellas se obtuvieron para la Real Hacienda sirvieron al Rey Católico para continuar las hostilidades con el país vecino. ${ }^{30}$

El parecer del Consejo de Hacienda con respecto a las licencias especiales, y aun con el modo en que se había llevado a cabo la represalia contra los franceses iniciada en 1635, la cual incluía como uno de sus puntos fundamentales la prohibición de comercio entre ambos estados, fue contundentemente contrario a la postura del Consejo de Estado. Con motivo de la apertura del comercio que a fines de 1639 publicó el Rey Cristianísimo, el Consejo de Estado estimó que debía cerrar todavía más el tráfico entre Francia y España «valiéndose Vuestra Majestad de permisiones particulares para traer a estos reinos lo necesario"; sin embargo los consejeros requirieron la opinión del Consejo de Hacienda antes de elevar al Rey su propuesta. Hacienda interpretó la medida de Luis XIII de un modo distinto a como lo hizo el C.onsejo de Estado, ya que según sus análisis la permisión dada por el Cristianísimo descubría los aprietos del reino de Francia, debidos con toda seguridad a los clamores de sus naturales para

${ }^{30}$ A.G.S., Contaduría del sueldo, $2^{\mathrm{a}}$ serie, legajo 159 ( $\sin$ foliar). 
el ajustamiento de la paz y el reestablecimiento de las relaciones comerciales, de las que aquéllos eran más dependientes. Por estas razones Hacienda postulaba el cierre absoluto de los mercados, así como la no concesión de licencia alguna; con lo que se daría a entender al Cristianísimo - proseguía el razonamiento de los consejeros- «que él no era el árbitro de la paz, ni de la guerra, ni del comercio, y que no dependía de su voluntad, sino de la de Vuestra Majestad ". ${ }^{31}$

El Consejo de Hacienda aprovechó la ocasión para expresar su opinión general sobre cómo se habían llevado las cosas en la represalia de 1635 contra los franceses, y sobre cuestiones de mayor calado relativas al comercio exterior y su administración, en especial en lo que tocaba al papel que los conversos portugueses jugaban en él. Primeramente argumentó que las llaves de Castilla eran los puertos de mar y tierra, y que éstos estaban en poder de portugueses, quienes habian continuado el comercio como antes de la prohibición, es decir, como si nada hubiese ocurrido, de modo que si no se ponía remedio a esa situación el Cristianísimo dispondría de caudal suficiente como para mantener la guerra, y sus vasallos no sentirían nunca la descomodidad de la falta de comercio. Hacienda sospechaba que quitar los puertos a los portugueses que los tenían arrendados no iba a ser una tarea fácil, por lo que valoraba la idea de enviar a ellos inspectores capaces y responsables para que examinasen todo lo que entraba y salía de la Península, lo que remediaría la mayor parte del daño. Hacienda también era consciente de la dificultad existente para averiguar el origen real de las manufacturas, al conocer que durante los años 1635 y 1636 los ingleses, "poniendo en sus cabezas las haciendas de holandeses y franceses" habían continuado el comercio, lo cual desvanecía el objetivo de las prohibiciones, de ahí que se hubiese comenzado a exigir a los mercaderes la posesión del libro público actualizado. Por añadidura, continuaba argumentado el Consejo de Hacienda, desde el año 37, "y con pretexto de venir las mercaderias de Inglaterra y encaminar a aquel reino las de este, se habian negociado los productos de Francia a España, lo cual había sido debido a las licencias y permisiones que se habían dado, y siempre que se dieran sucedería lo mismo". Con lo cual el Consejo rechazaba de plano la concesión de permisos especiales, pues el daño que causaban era conocido y evidente.

Continuando su alegato contra las permisiones, el Consejo de Hacienda explicitó que con una licencia de cien mil ducados se introducían mercancías por valor de 200.000 y más, porque estos permisos se daban a portugueses, y como los puertos estaban en su poder, la cantidad se regulaba

3' A.H.N., Consejos, legajo 7.119 (27). Todas estas ideas y análisis se hallan recogidos más pormenorizadamente en Pellicer y Tovar, Joseph, Comercio impedido por los enemigos de esta Monarquía. Madrid, 1939. 
a su voluntad "y así se tiene entendido que con ocasión de ellas se han metido en estos reinos sumas grandes de mercaderías». El Consejo reconocía que estas licencias se daban para reparo de mayores necesidades, pero por el efecto que de ellas se seguía era mejor no concederlas. Yendo incluso más lejos, los miembros del Consejo pidieron al Rey que revisase las que se habían dado hasta entonces, con el objeto de impedir el uso de las que ya estaban cumplidas y suspender las que quedaban por ejecutar. Sin embargo, no parece que Felipe IV siguiera los avisos que con tan contundentes argumentos le habían ofrecido los expertos de su Consejo, porque la expedición de licencias continuó su curso habitual, al haberse erigido en una buena vía de allegar recursos. Así, en 1642 Adrian Paez consiguió de nuevo una licencia por valor de 300.000 ducados para introducir en Castilla mercancías de contrabando, a cambio del adelanto del dinero suficiente como para comprar los caballos que se necesitaban para la Jornada de Aragón. ${ }^{32}$

Todavía a fines del decenio $1640-50$ se concedieron múltiples permisos para introducir mercancías, unas veces de contrabando y otras legales pero sin considerar apenas los estancos que había sobre ellas. El 23 abril 1649, Thomas de Santa Coloma, vecino de Bilbao, se obligó a pagar en octubre del mismo 12.150 reales "con que sirve a Su Majestad por la permisión para introducir 1.620 quintales de tabaco". Aquel mismo mes y año se permitió a Juan Jiménez Jurado, vecino de Málaga, introducir 10.000 quintales de bacalao de Francia, obligándose a pagar 2.400 ducados por la licencia. También en 1649, Guillermo Pauley, el conocido mercader y contrabandista inglés, se obligó a pagar 12.000 ducados, mitad de contado y mitad para julio de 1650, para introducir por Bilbao y San Sebastián 100.000 ducados de azúcar, algodón, jengibre, tabaco y frutos que beneficiaban ingleses en las islas de Barbados, San Cristóbal y Virginia, pero con la obligación de traer testimonios auténticos de que eran frutos procedentes de ellas, y debiendo además ser consumidos exclusivamente en Vizcaya y Guipúzcoa. ${ }^{33}$

\section{ALGUNAS REFLEXIONES FINALES.}

Para concluir habría que preguntarse acerca de la efectividad y posibilidades de la Junta del Almirantazgo en la lucha contra el contrabando. Se ha podido comprobar por los ingresos de la institución que ésta no recau-

${ }^{5}$ Sanz Ayan, C., “Negociadores y capitales holandeses en los sistemas de abastecimiento de pertrechos navales de la Monarquía Hispánica durante el siglo XVII", Hispania, 188 (1992), pp. 915-945, p. 932.

${ }^{33}$ A.G.S., Contaduria del sueldo, $2^{\mathrm{a}}$ serie, legajo 117 ( $\sin$ foliar). 
dó todo lo que debía o podía. Por sus libramientos y gastos se ha constatado asimismo que la Real Hacienda no se benefició directamente de los decomisos que efectuaban los veedores. Por añadidura, observando la actividad de las redes de contrabando y la reincidencia de sus integrantes en el comercio ilegal, ha quedado claro que no se reprimió el fenómeno como las leyes prescribían. Y sin embargo no se puede afirmar que la Junta del Almirantazgo, y aun la propia Monarquia, abandonasen la lucha o no le prestaran la atención debida. Antes al contrario, los veedores desarrollaron una labor encomiable contra el comercio ilegal, si bien la represión se encauzó por otras vías distintas de las de la justicia ordinaria. Pulido Bueno ha destacado que la eficacia del Almirantazgo en la defensa de los intereses de la Monarquía se dejó entrever por la presión de los países europeos para anular legalmente las facultades que tenía en el control del comercio exterior. Existen muchos testimonios que corroboran estas premisas, algunos de los cuales se han apuntado en las páginas antecedentes, pero nosotros nos quedamos con el de un protagonista: Bartolomé Febo reconoció haber perdido en España mucha hacienda debido a los múltiples pleitos que protagonizó y a las condenaciones que sufrió por parte del Almirantazgo. ${ }^{34}$ En suma, podemos afirmar que se trató de combatir el contrabando hasta tenerlo controlado, pero no erradicarlo, porque así se garantizaba el abasto de los mercados y de determinados recursos cuando las necesidades apremiaban.

Herrero Sánchez también ha reflexionado recientemente sobre este fenómeno, y algunas de sus conclusiones confirman estos análisis. El autor apunta que los embargos no eran capaces de impedir la entrada de productos enemigos, pero sí servían para privilegiar a unas comunidades mercantiles sobre otras, siendo ahí donde radicaba en esencia el interés de tales medidas de bloqueos comerciales: "la Corona española -afirmaera consciente de que la viabilidad de la guerra económica aumentaba si lograba tener abastecidos sus mercados por un aliado capaz de cubrir la demanda «. En el mismo sentido Ildefonso Pulido ha afirmado que más que imponer una ruptura total del comercio con los enemigos, la Monarquía buscó un procedimiento que regulase las relaciones económicas con ellos, pero orientado a sus intereses.

En otro orden de cosas, los valores registrados por los Almojarifazgos Mayor y de Indias analizados por lldefonso Pulido, muestran un declive importante a partir de 1621, llegando incluso a disminuir a la mitad después de esa fecha, para después no remontar el vuelo ni aproximarse a los índices conseguidos a fines del siglo XVI y comienzos del siguiente. Aún más, a partir de 1630 el descenso de las recaudaciones de dichas aduanas

"BELINChón, "Sacar la sustancia del reino". Op. cit., pág 1.035. 
fue tan considerable que sus arrendadores entraron irremisiblemente en quiebra, y aunque en 1646 se arrendaron a precios más bajos no se logró evitar una gestión ruinosa. La pregunta que convendría hacerse sobre estos registros fiscales es si esa disminución constatada podría extrapolarse a los valores totales del comercio exterior de Andalucía - a falta de series prolongadas para otros puertos del Norte- y en caso afirmativo, si esa merma registrada oficialmente fue suplida $-y$ hasta qué punto- por el contrabando. No resulta fácil, con los datos disponibles, establecer balances fiables que respondan las preguntas formuladas más arriba, pero existen elementos que al menos pueden orientarnos sobre el alcance económico producido por los distintos bloqueos comerciales y, en última instancia, sobre el papel jugado por el contrabando en la guerra económica.

En 1628 el embajador de Francia estimó el valor total de las exportaciones de lienzos de algodón franceses a España en cinco millones de escudos de oro, resultantes de los 15 millones de libras anuales de esos tejidos que entraban principalmente por Sanlúcar, Cádiz y Sevilla. Quince años más tarde, en 1640, Joseph Pellicer estimó el capital francés en la península en tres millones y medio de pesos, de entre los siete y nueve millones de libras que entraban por Andalucía; y ello teniendo en cuenta que entre 1636 y 1640 se dieron licencias especiales por valor de 4,5 millones de ducados para introducir mercancías de Francia. ${ }^{35}$ Es lógico pensar que la guerra, la represalia y la prohibición del comercio fuesen los causantes de semejante descenso en las exportaciones francesas a España, como también lo es admitir que el bloqueo fue casi tan eficaz como se quiso que fuera, pues las mercancías de Francia se introdujeron ya mediante licencias especiales, ya mediante un contrabando semicontrolado.

Otro factor que pudo hacer incrementar el contrabando y todo tipo de descaminos en la primera mitad del siglo XVII fue el aumento de los impuestos sobre los artículos del comercio exterior, tanto a la entrada como a la salida. Si bien, Pulido Bueno sostiene que el contrabando no adquirió pautas de gran volumen y continuidad hasta después de 1648 , favorecido por los altísimos impuestos decretados los años anteriores a esa fecha, el descenso de la producción manufacturera nacional, y naturalmente las buenas posibilidades de lucro que representa la coyuntura para muchos ciudadanos deseosos de dinero. ${ }^{36}$ Los impuestos en los Almojarifazgos llegaron al 19 por ciento en 1635 , al 22 por cien diez años más tarde, y alcanzaron el 33 por 100 en 1666. Para los productos de reexportación

${ }^{35}$ Girard, A., Le Commerce FranÇais a Séville et Cadix au temps des Habsbourg. París, 1932 (edición citada de 1967) págs. 349-353.

${ }^{36}$ Incluso llega a decir que no es exagerado considerar que en el área de Cádiz el comercio de contrabando se aproximase superase el registrado en las aduanas. Pulido Bueno, I., Almojarifazgos y comercio exterior. Op. cit., págs. 110-114. 
provenientes de Indias las cargas eran aún mayores: los derechos de entrada llegaban a un 30 por ciento del valor tasado de ellos, salvo el azúcar, que lo incrementaba en un 40 por cien; los de salida oscilaban entre un 10 y un 20 por ciento, según las mercancias de que se tratase.

En suma, de los datos ofrecidos se desprende que la lucha contra el contrabando estuvo encaminada a controlarlo, y que por muchos artículos que se introdujesen a espaldas de los veedores, o con su propia aquiescencia, no eran suficientes como para llenar los huecos producidos por las prohibiciones de comercio. Por añadidura, cuando se necesitaban géneros como textiles para las Indias, o bacalao, trigo y pertrechos navales para la Península, se expedían licencias que permitían contratarlos con toda garantía, salvando claro está los problemas ocasionados para transportarlos. De resultas de todo lo cual se puede concluir que las medidas de guerra económica concebidas por los Austrias para neutralizar a sus más directos rivales en la carrera por el dominio del comercio mundial no fueron mínimas e ineficaces. En consecuencia el fracaso de su política deberá en buscarse en otras partes.

Sin duda las Indias no eran la causa de "hallarse estos reinos con poca población, y sin plata, cargados de obligaciones de política costosa en trajes, y gastos" como rezaba la carta con que se iniciaba este artículo. Pero de acuerdo con el veedor de comercio y memorialista Francisco de Retama, tampoco hacían falta las Indias para conseguir la prosperidad de la Monarquía, «pues Venecia, Génova y Holanda, Francia e Inglaterra y Polonia, no tenían plata ni oro ni indias de donde traerlo, ... pero les entraban grandes tesoros por sus tratos ... ya que éstos ponen ingenio a los hombres y ellos con su industria son las verdaderas indias", mientras España, según Retama, estaba enajenada de sus propias riquezas. 
Contrabando y contrabandistas aprehendidos por la Junta del Almirantazgo, 1626-1639.

\begin{tabular}{|c|c|c|c|c|}
\hline Año & Procedencia & Contrabando & Condenado & Cargo \\
\hline & & & & (maravedles) \\
\hline 1626 & & navio y carga de trigo & Jarish Banderley & 2945740 \\
\hline 1629 & Madrid & 803 libras de clavo de especia & & 900966 \\
\hline 1630 & Reino de Galicia & tejidos ingleses y otras mercanclas & & 431183 \\
\hline \multirow[t]{8}{*}{1631} & Lisboa & bayetas y otras mercanclas & & 1326000 \\
\hline & Sevilla & contrabando & Joan Folinque, Miguel Galle & 1604940 \\
\hline & Castrourdiales & anascotes, sargas, medias... & & 477852 \\
\hline & Madrid & contrabando & Simón Sanz & 106590 \\
\hline & Pamplona & contrabando & Juan de Zabalza & 660372 \\
\hline & sin especificar & 4 barriles de goma & & 28560 \\
\hline & sin especificar & diferentes mercaderìas & Pablo Sonio, Fernando GŨmez Pardo, P. & \\
\hline & & & Fern-ndez Pato y Melchor Núñez Peña & 710470 \\
\hline \multirow[t]{5}{*}{1632} & Santander & 290 piezas de fustanes & Simón Núñez Soto & 246500 \\
\hline & Pontevedra & anascotes y lanillas & & 328100 \\
\hline & sin especificar & goma & Fonseca, Méndez, Enríquez, Febos... & 1500000 \\
\hline & sin especificar & diferentes mercaderìas & Juan Yruega & 20230 \\
\hline & sin especificar & 350 gruesas de agujetas & Antonio Enrlquez & 29750 \\
\hline \multirow[t]{16}{*}{1633} & Algarve & un fardo de anascotes & MÉndez de Olivera & 37500 \\
\hline & Isla de la Madera & 88 piezas de bayetos Hamburgo & Benitos de Matos (composiciÜn) & 396950 \\
\hline & Lisboa & 26 piezas de filipichines & Luis de Olivera & 61880 \\
\hline & Madrid & ruanes, medias Cambrais y alfileres & Diego Ureña y Pedro Betat & 198246 \\
\hline & Bilboo & Merc. Navio Sacrificio de Abrahan & Guillermo Pauley y mercaderes ingleses & 6064036 \\
\hline & Sevilla & contrabondo & Pedro Potruit y Doniel de LeÛn & 251600 \\
\hline & sin especificar & agujełas & Pedro Gonz-lez & 28815 \\
\hline & sin especificar & 220 docenas de becerros & Pedro MÉndez & 149600 \\
\hline & sin especificar & contrabando & Jorge Enrìquez & 22916 \\
\hline & sin especificar & 103 varas de rasas & Pedro Martinez & 10149 \\
\hline & sin especificar & contrabando & Giraldo Laurische & 319924 \\
\hline & sin especificar & groserlas & Thomas Rodrìguez Pereira & 28186 \\
\hline & sin especificar & 32 piezas de bocacles & P. Antonio Madona & 17408 \\
\hline & sin especificar & 1256 libras de goma & Pedro Aaron & 53380 \\
\hline & sin especificar & 14 barriles de goma & Guillermo Pauley & 44200 \\
\hline & sin especificar & 6 barriles de goma & Pedro Brocarte & 13600 \\
\hline \multirow[t]{20}{*}{1634} & Sevilla & goma, anascotes y caparrosa & & 180846 \\
\hline & Sevilla & condena de tres navios: San Maló, S & an Vicente y San Pedro & 907732 \\
\hline & Viona & bayetas y atras mercaderlas & Pedro Fern-ndez Pato & 217014 \\
\hline & Oporto & sorgas & Pantale Ûn de Pazos & 113764 \\
\hline & Cortagena & contrabondo & Francisco Serra & 169286 \\
\hline & Cartagena & 125 piezas de cameloles & Julio César Escareola & 157818 \\
\hline & San Sebasti-n & 3853 libras de goma & Petruen Cuaton & 163744 \\
\hline & Ciudad Real & 30 piezas de anascotes & Diego Rodrlguez & 89760 \\
\hline & Almuñécar & Mercanclas Navlo la Salamandra & & 788800 \\
\hline & sin especificar & Lanillas y estameña & Álvaro Díaz y Cristóbal da Costa & 41344 \\
\hline & sin especificor & cintas y cotonias & AndrÈs LÛpez & 52836 \\
\hline & sin especificar & dos barriles de goma & Francisco Rodriguez & 5100 \\
\hline & sin especificar & nueve barriles de goma & Carlos Leba & 132804 \\
\hline & sin especificar & 18 tijeras de fundidor y 288 frascos & Adrian Póez & 60656 \\
\hline & sin especificar & bocacles & Juan Bautista San Julián & 300000 \\
\hline & sin especificar & 64 piezas de bocacles & Pedro y Bartolomé de Miranda & 34000 \\
\hline & sin especificar & 150 libras de inciencso & Francisco GÜmez & 15300 \\
\hline & sin especificar & agujetas, pelo de oro, medias & Francisco Rodrlguez & 258026 \\
\hline & sin especificar & contrabando & Martin Culeybar & 13666 \\
\hline & sin especificor & 40 docenas de becerras & Antonio Brandon & 19642 \\
\hline \multirow[t]{6}{*}{1635} & San Sebastión & 5 fardos de alfiteres & & 53040 \\
\hline & Viana & picotes, terciopelo & Martin Bello & 264902 \\
\hline & Isla de la Madera & 1/3 del navlo el Ruisecor & Diego Fern nidez Blanco -composic.- & 109016 \\
\hline & Lisboa & alcance del veedor de contrabondo & Alonso de Alarến & 89696 \\
\hline & Sovilla & contrabando & Francisco Vinq $y$ Vicente Indelmon & 633046 \\
\hline & Sevilia & paños y antepuertas de Tornay & Thomas Boom & 53656 \\
\hline
\end{tabular}




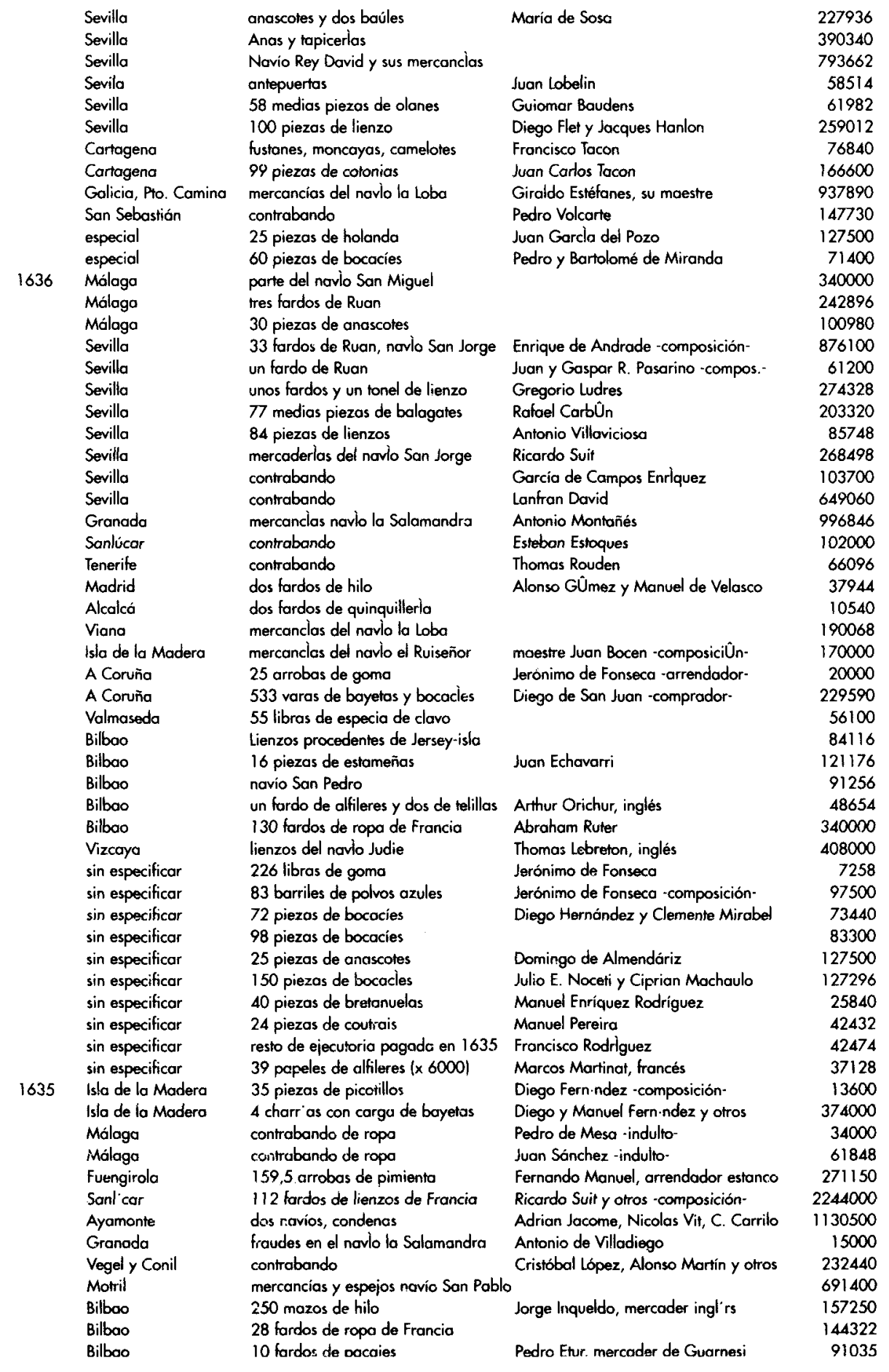




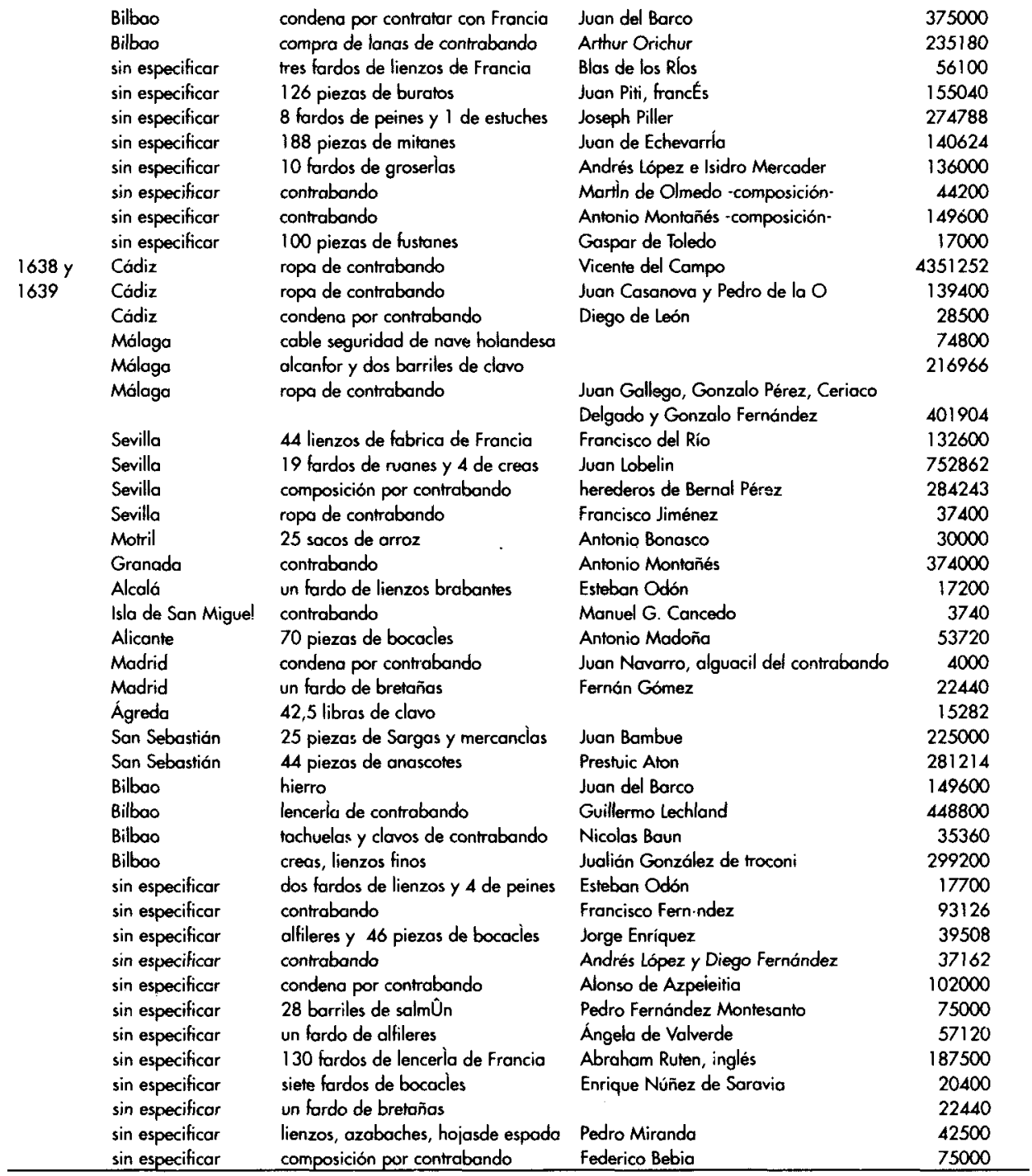

FUENTE: elaboración propia a partir de A.G.S., Contadurla del sueldo $\left(2^{\circ}\right.$ serie) legajo 162. 